\title{
Desymmetrized Diiron Azadithiolato Carbonyls: A Step Toward Modeling the Fe-only Hydrogenases
}

\author{
Jane L. Stanley, Zachariah M. Heiden, Thomas B. Rauchfuss* ${ }^{*}$ Scott R. Wilson \\ Department of Chemistry, University of Illinois at Urbana-Champaign, Urbana, IL, 61801 \\ Rauchfuz@uiuc.edu \\ Luca De Gioia and Giuseppe Zampella \\ Department of Biotechnology and Biosciences \\ University of Milano-Bicocca \\ Piazza della Scienza 1 \\ 20126-Milan \\ Italy
}

\section{Supporting Information}

Index

NMR, IR and Kinetic Data

1) Molecular Structure of $\mathrm{Fe}_{2}\left[\left(\mathrm{SCH}_{2}\right)_{2} \mathrm{NH}\right](\mathrm{CO})_{6} \quad \mathrm{~S} 2$

2) $\mathrm{NMR}$ Data for $\mathrm{Fe}_{2}\left[(\mathrm{SCHMe})_{2} \mathrm{NH}\right](\mathrm{CO})_{6} \quad \mathrm{~S} 3$

3) $\mathrm{NMR}$ Data for $\mathrm{Fe}_{2}\left[(\mathrm{SCHMe})_{2} \mathrm{NH}\right](\mathrm{CO})_{4}\left(\mathrm{PMe}_{3}\right)_{2} \quad \mathrm{~S} 6$

4) $\quad \mathrm{NMR}$ Data for $\mathrm{Fe}_{2}\left[(\mathrm{SCHMe})_{2} \mathrm{NH}\right](\mathrm{CO})_{5}\left(\mathrm{PPh}_{3}\right) \quad \mathrm{S} 8$

5) Comparison of IR Spectra for $\mathrm{Fe}_{2}\left[\left(\mathrm{SCH}_{2}\right)_{2} \mathrm{NH}\right](\mathrm{CO})_{6}$ and

$\mathrm{Fe}_{2}\left[\left(\mathrm{SCH}_{2}\right)_{2} \mathrm{NH}\right](\mathrm{CO})_{6}$ where $\mathrm{R}=t-\mathrm{Bu}$ and $\mathrm{H} \quad \mathrm{S} 9$

6) Kinetic Data for Tautomerization of

$\left[\mathrm{Fe}_{2}\left[(\mathrm{SCHR})_{2} \mathrm{NH}_{2}\right](\mathrm{CO})_{4}\left(\mathrm{PMe}_{3}\right)_{2}\right]^{+}$to

$\left[\mathrm{Fe}_{2}\left[(\mathrm{SCHMe})_{2} \mathrm{NH}\right](\mu-\mathrm{H})(\mathrm{CO})_{4}\left(\mathrm{PMe}_{3}\right)_{2}\right]^{+}($where $\mathrm{R}=\mathrm{Me}, \mathrm{H}) \quad \mathrm{S} 10$

$p K_{a}$ Determinations

7) Experimental for $\mathrm{pK}_{\mathrm{a}}$ Determination $\quad \mathrm{S} 13$

8) Data Analysis for $\mathrm{pK}_{\mathrm{a}}$ Determination $\quad \mathrm{S} 14$

A) Multi-Gaussian Fit in Origin $\quad$ S14

B) Data Manipulation Using Excel and Gaussian Fit Results $\begin{array}{ll}\text { with Origin } & \text { S20 }\end{array}$

C) Manual Adjustment of Gaussian Fits $\quad$ S21

D) Obtaining Final Area Values Using Re-fitted Data S22 
9) Equations used in $\mathrm{pK}_{\mathrm{a}}$ Determination

10) Sample Gaussian Fits From Origin (before Excel re-fit) for $\mathrm{Fe}_{2}\left[(\mathrm{SCHMe})_{2} \mathrm{NH}\right](\mathrm{CO})_{6}$.

11) Sample Gaussian Visual Re-Fits From Excel for $\mathrm{Fe}_{2}\left[(\mathrm{SCHMe})_{2} \mathrm{NH}\right](\mathrm{CO})_{6}$.

DFT Results

12) DFT relative energies for $\mathrm{CH}_{2}(\mathrm{CHMe})_{2} \mathrm{~S}_{2} \mathrm{NH}$ isomers

13) $\quad v \mathrm{CO}\left(\mathrm{cm}^{-1}\right)$ computed for $\mathrm{Fe}_{2}\left[(\mathrm{SCHMe})_{2} \mathrm{NH}\right](\mathrm{CO})_{6}$ and $\left[\mathrm{Fe}_{2}\left[(\mathrm{SCHMe})_{2} \mathrm{NH}_{2}\right](\mathrm{CO})_{6}\right]^{+}$

14) Minimized Structures for $\mathrm{Fe}_{2}\left[(\mathrm{SCHMe})_{2} \mathrm{NH}\right](\mathrm{CO})_{6}$

15) Reference

S31

\section{NMR, IR and Kinetic Data}

\section{1) Molecular Structure of $\mathrm{Fe}_{2}\left[\left(\mathrm{SCH}_{2}\right)_{2} \mathrm{NH}\right](\mathrm{CO})_{6}$}

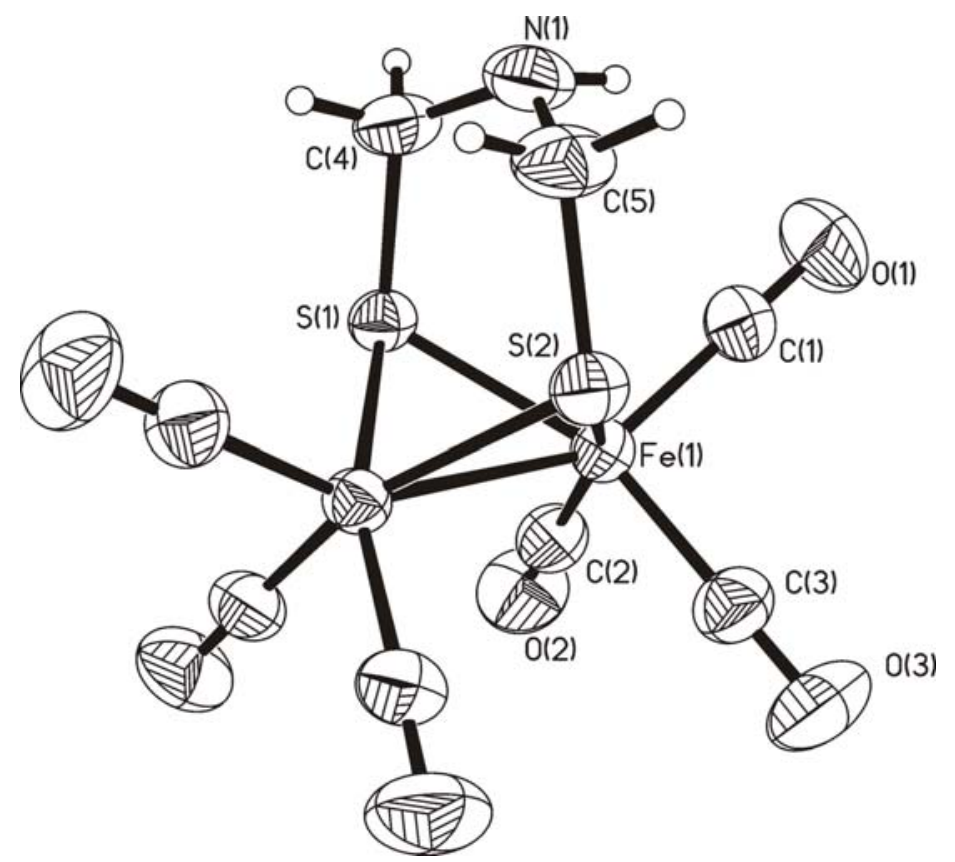

Figure S1. Molecular structure of $\mathrm{Fe}_{2}\left[\left(\mathrm{SCH}_{2}\right)_{2} \mathrm{NH}\right](\mathrm{CO})_{6}$ with thermal ellipsoids drawn at the $50 \%$ probability level. 


\section{2) NMR Data for $\mathrm{Fe}_{2}\left[(\mathrm{SCHMe})_{2} \mathrm{NH}\right](\mathrm{CO})_{6}$}
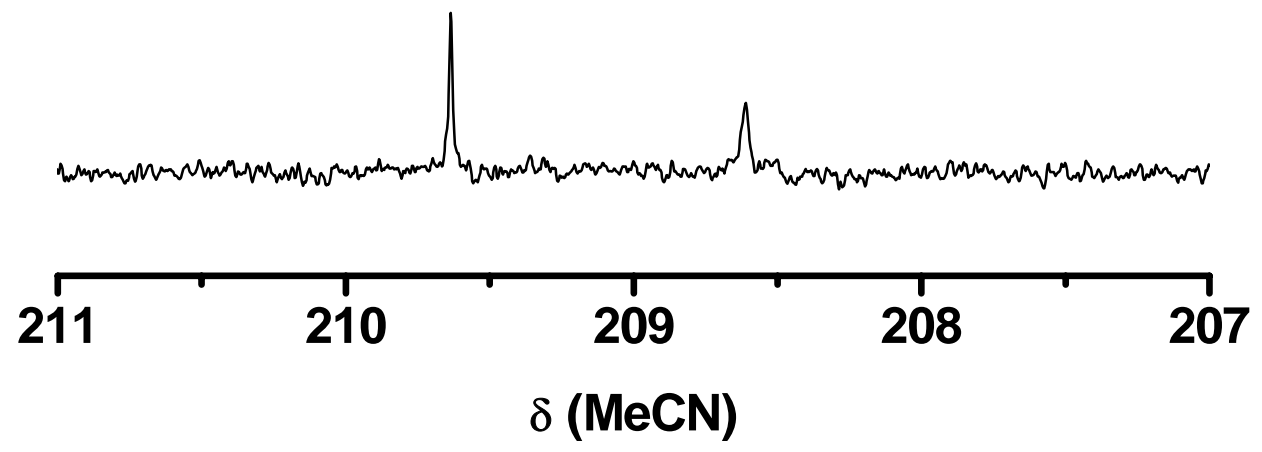

Figure S2. ${ }^{13} \mathrm{C} N M R\left(\mathrm{CD}_{3} \mathrm{CN}\right)$ spectrum of $\mathrm{Fe}_{2}\left[(\mathrm{SCHMe})_{2} \mathrm{NH}\right](\mathrm{CO})_{6}$ corresponding to the $\mathrm{CO}$ - region.

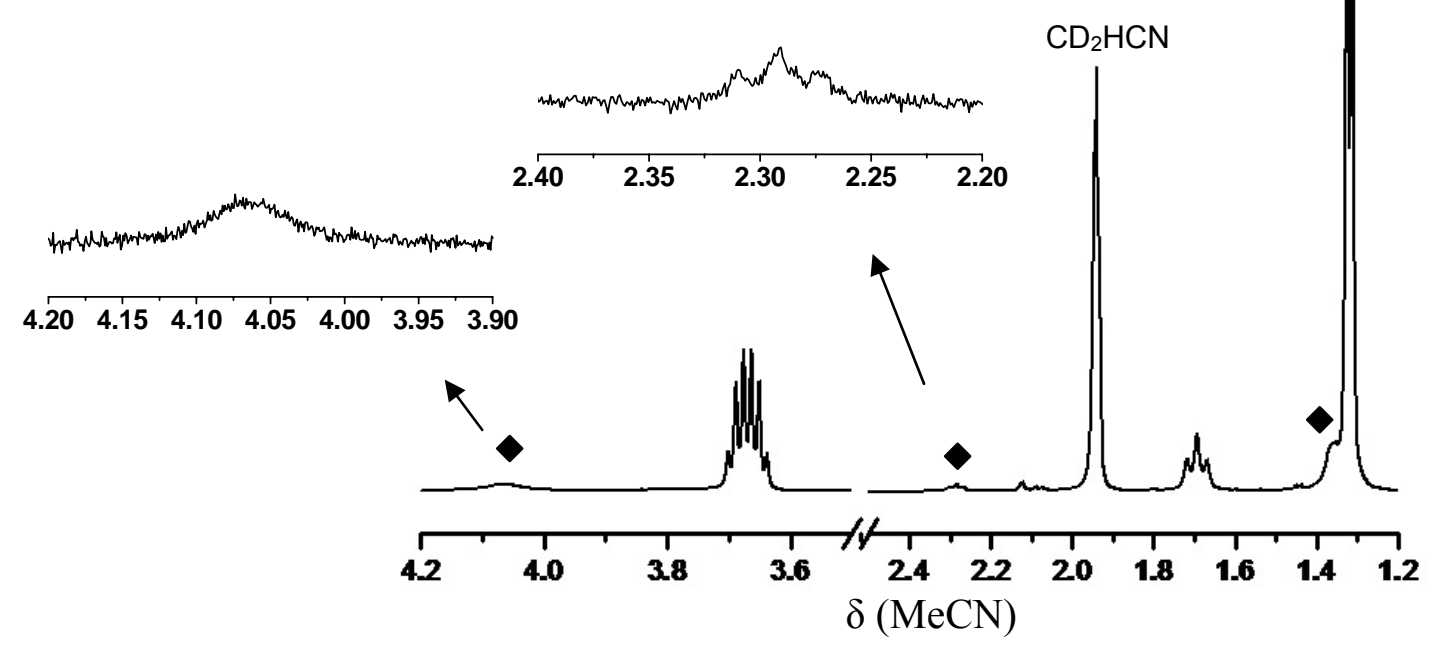

Figure S3. $500 \mathrm{MHz}{ }^{1} \mathrm{H} \mathrm{NMR}$ spectrum of the $\mathrm{Fe}_{2}\left[(\mathrm{SCHMe})_{2} \mathrm{NH}\right](\mathrm{CO})_{6}$ in $\mathrm{CD}_{3} \mathrm{CN}$. The signals $(\diamond)$ at $\delta 4.07,2.30$, and 1.35 (see insets) are assigned to the $d, l$ isomer. 


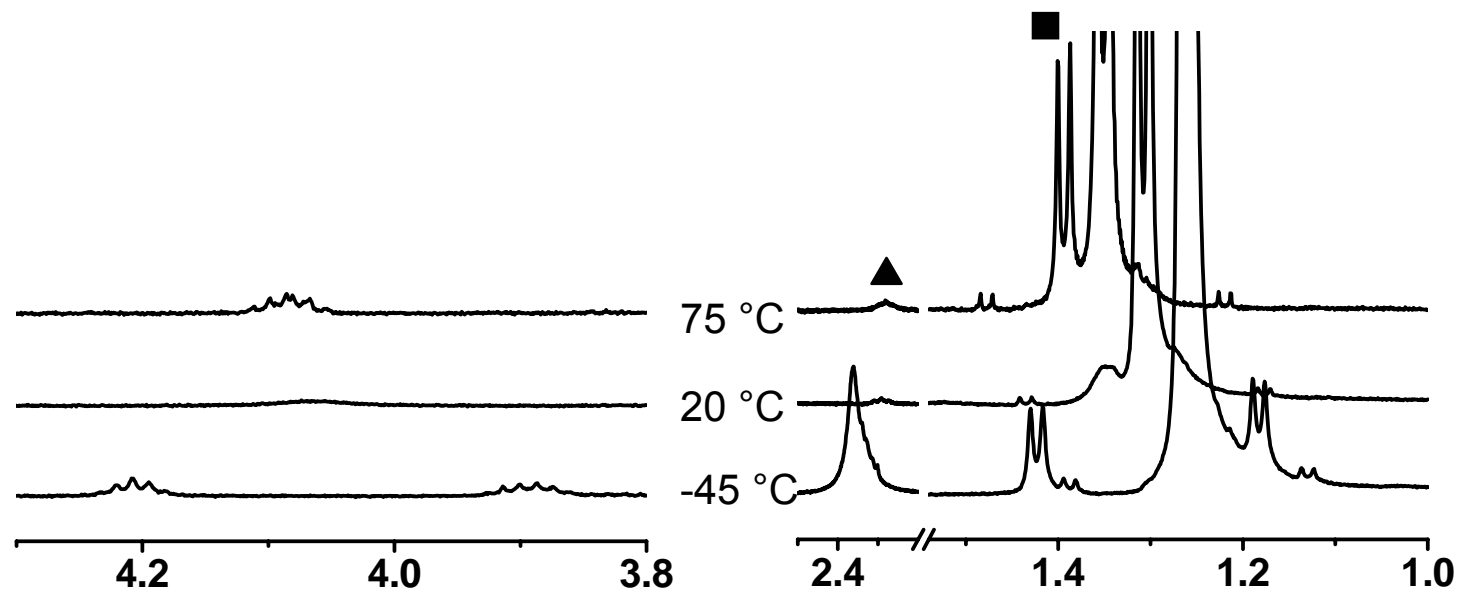

Figure S4. $500 \mathrm{MHz}^{1}{ }^{1} \mathrm{H}$ NMR spectra of $\mathrm{Fe}_{2}\left[(\mathrm{SCHMe})_{2} \mathrm{NH}\right](\mathrm{CO})_{6}$ in $\mathrm{CD}_{3} \mathrm{CN}$ at selected temperatures focusing on the $d$, l-isomer signals. Subspectrum A corresponds to the SCHMe ( $\square$ ) and signals in subspectrum B shows the $\mathrm{NH}$ signal $(\boldsymbol{\Delta})$. Note: for the spectrum at $-45^{\circ} \mathrm{C}$, the signals for $\mathrm{NH}(\boldsymbol{\Delta})$ and $\mathrm{H}_{2} \mathrm{O}$ overlap). 
Table S1. The integrations with respect to time and temperature $\left(50^{\circ} \mathrm{C}\right)$ of meso: $d, I$ for both the $\mathrm{CH}$ and the $\mathrm{NH}^{1} \mathrm{H}$ NMR signals. The meso-integrations were initially calibrated to the integration standard $\left(\mathrm{Ph}_{3} \mathrm{CH}\right)$ before integrations of the $d, l$ isomer were determined with respect to the meso.

\begin{tabular}{|c|lll|lll|}
\hline Time $(\min )$ & meso-(CH) & $:$ & $d, I-(\mathrm{CH})$ & meso-(NH) & $:$ & $d, I-(\mathrm{NH})$ \\
\hline $0(\mathrm{RT})$ & 1 & $:$ & 0.0708 & 1 & $:$ & 0.0886 \\
\hline 45 & 1 & $:$ & 0.0661 & 1 & $:$ & 0.0809 \\
\hline 90 & 1 & $:$ & 0.0627 & 1 & $:$ & 0.0766 \\
\hline 135 & 1 & $:$ & 0.0659 & 1 & $:$ & 0.0790 \\
\hline 300 & 1 & $:$ & 0.0677 & 1 & $:$ & 0.0987 \\
\hline 1095 & 1 & $:$ & 0.0639 & 1 & $:$ & 0.0789 \\
\hline
\end{tabular}


3) NMR Data for $\mathrm{Fe}_{2}\left[(\mathrm{SCHMe})_{2} \mathrm{NH}\right](\mathrm{CO})_{4}\left(\mathrm{PMe}_{3}\right)_{2}$

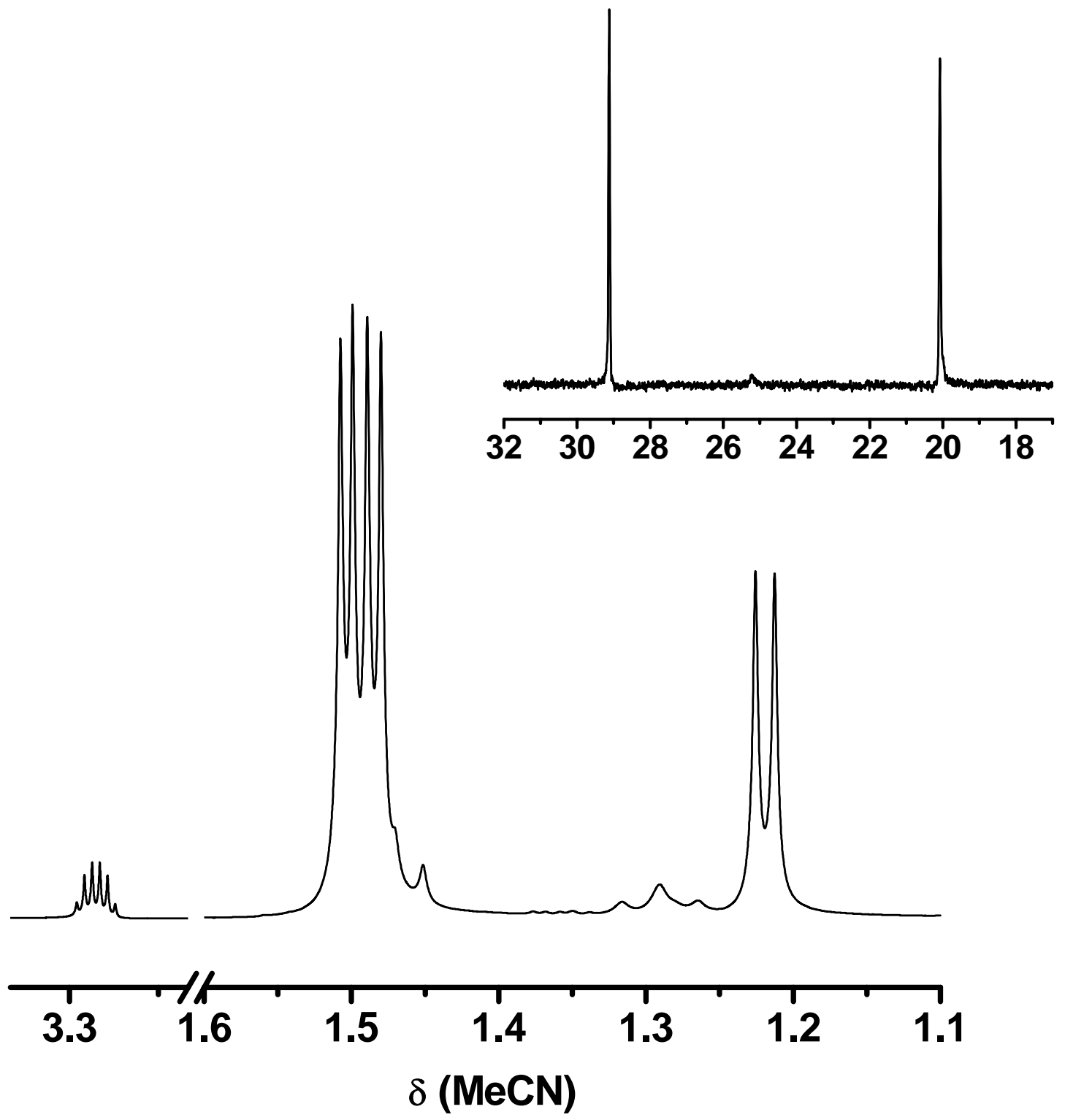

Figure S5. ${ }^{1} \mathrm{H} \mathrm{NMR}\left(\mathrm{CD}_{3} \mathrm{CN}\right)$ spectrum of $\mathrm{Fe}_{2}\left[(\mathrm{SCHMe})_{2} \mathrm{NH}\right](\mathrm{CO})_{4}\left(\mathrm{PMe}_{3}\right)_{2}$ with the ${ }^{31} \mathrm{P}$ NMR $\left(\mathrm{CD}_{3} \mathrm{CN}\right)$ spectrum in the inset showing. The solvent peak has been removed from the ${ }^{1} \mathrm{H}$ NMR spectrum for clarity. 


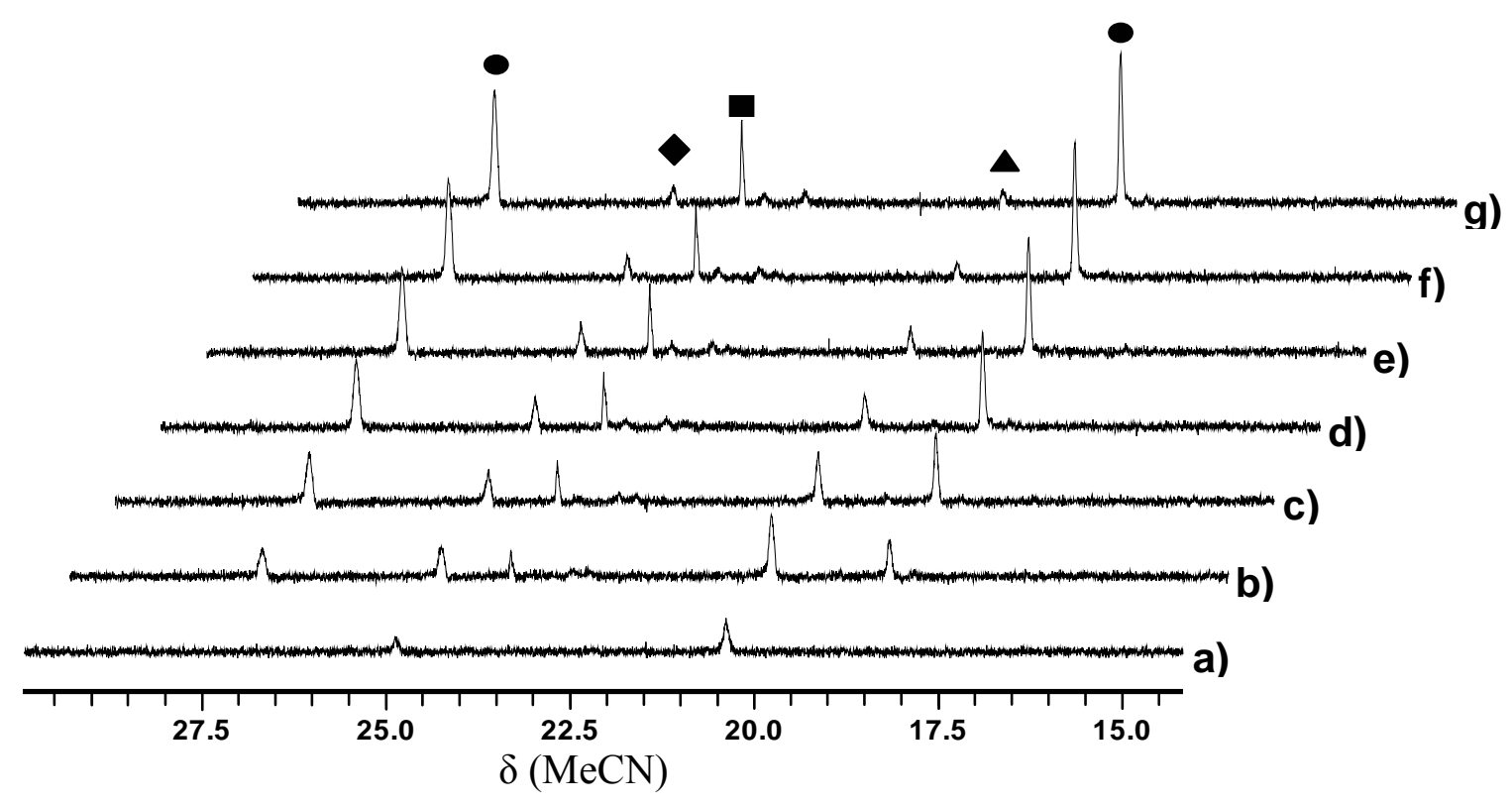

Figure S6. ${ }^{31} \mathrm{P}$ NMR spectra of the reaction of excess $\mathrm{PMe}_{3}$ with 1 in $\mathrm{CD}_{3} \mathrm{CN}$ at $50{ }^{\circ} \mathrm{C}$, where times (in min.) are as follows: a) 5 , b) 15 , c) 25 , d) 35 , e) 45 , f) 55 and g) 65. Assignments: $\mathrm{Fe}_{2}\left[(\mathrm{SCHMe})_{2} \mathrm{NH}\right](\mathrm{CO})_{5}\left(\mathrm{PMe}_{3}\right)(\boldsymbol{\Delta}, \diamond)$, $\mathrm{Fe}_{2}\left[(\mathrm{SCHMe})_{2} \mathrm{NH}\right](\mathrm{CO})_{4}\left(\mathrm{PMe}_{3}\right)_{2}(\bullet)$. Signal labeled $\boldsymbol{\square}$ is assigned to $d, l-$ $\mathrm{Fe}_{2}\left[(\mathrm{SCHMe})_{2} \mathrm{NH}\right](\mathrm{CO})_{5}\left(\mathrm{PMe}_{3}\right)$. 
4) NMR Data for $\mathrm{Fe}_{2}\left[(\mathrm{SCHMe})_{2} \mathrm{NH}\right](\mathrm{CO})_{5}\left(\mathrm{PPh}_{3}\right)$

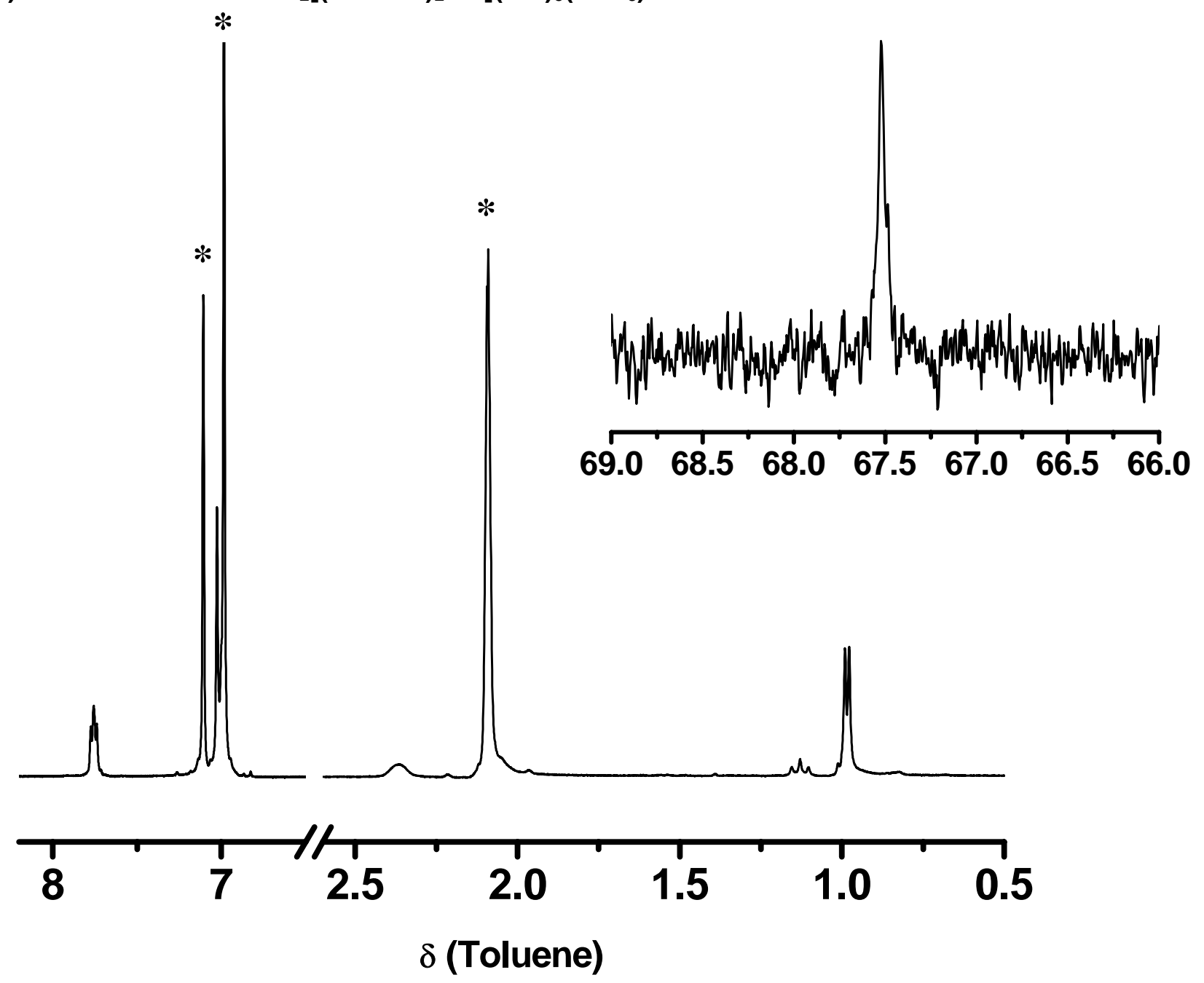

Figure S7. The ${ }^{1} \mathrm{H}$ NMR (toluene- $\mathrm{d}_{8}$ ) spectrum of $\mathrm{Fe}_{2}\left[(\mathrm{SCHMe})_{2} \mathrm{NH}\right](\mathrm{CO})_{5}\left(\mathrm{PPh}_{3}\right)$ with the ${ }^{31} \mathrm{P}$ NMR (toluene- $\left.\mathrm{d}_{8}\right)$ spectrum as an inset showing only one isomer is present. Peaks corresponding to * are solvent. 
5) Comparison of IR Spectra for $\mathrm{Fe}_{2}\left[\left(\mathrm{SCH}_{2}\right)_{2} \mathrm{NR}\right](\mathrm{CO})_{6}$, where $\mathrm{R}=\mathrm{Me}$, t-Bu, and $\mathrm{H}$

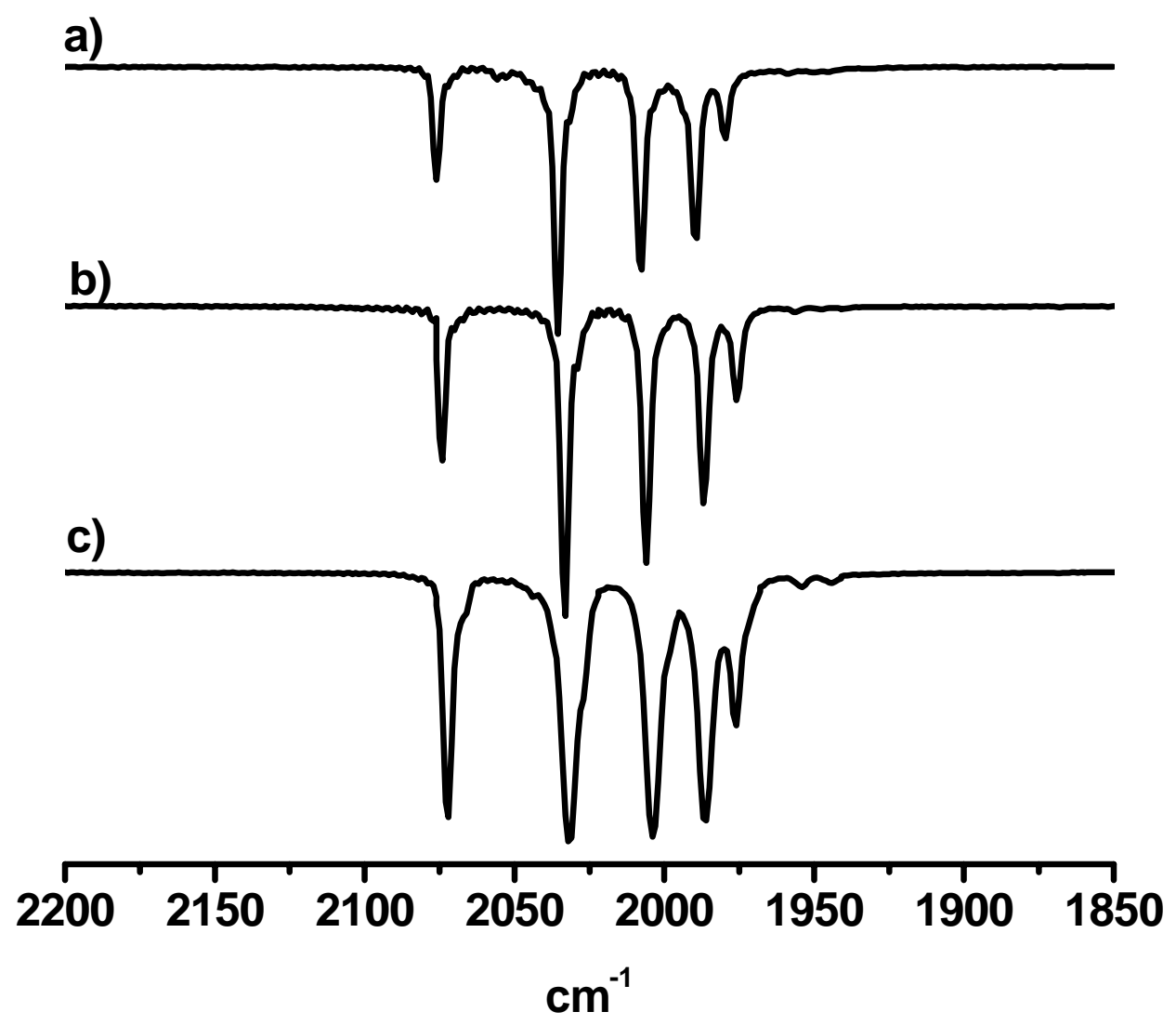

Figure S8. IR spectra in hexanes comparing the $v_{\mathrm{CO}}$ signitures of a) $\mathrm{Fe}_{2}\left[\left(\mathrm{SCH}_{2}\right) \mathrm{NH}\right](\mathrm{CO})_{6}$, b) $\mathrm{Fe}_{2}\left[(\mathrm{SCHMe})_{2} \mathrm{NH}\right](\mathrm{CO})_{6}$, and c) $\mathrm{Fe}_{2}\left[(\mathrm{SCHMe})_{2} \mathrm{~N}\right.$-t$\mathrm{Bu}](\mathrm{CO})_{6}$. 
6) Kinetic Data for Tautomerization of $\left[\mathrm{Fe}_{2}\left[(\mathrm{SCHR})_{2} \mathrm{NH}_{2}\right](\mathrm{CO})_{4}\left(\mathrm{PMe}_{3}\right)_{2}\right]^{+}$to $\left[\mathrm{Fe}_{2}\left[(\mathrm{SCHMe})_{2} \mathrm{NH}\right](\mu-\mathrm{H})(\mathrm{CO})_{4}\left(\mathrm{PMe}_{3}\right)_{2}\right]^{+}($where $\mathrm{R}=\mathrm{Me}, \mathrm{H})$
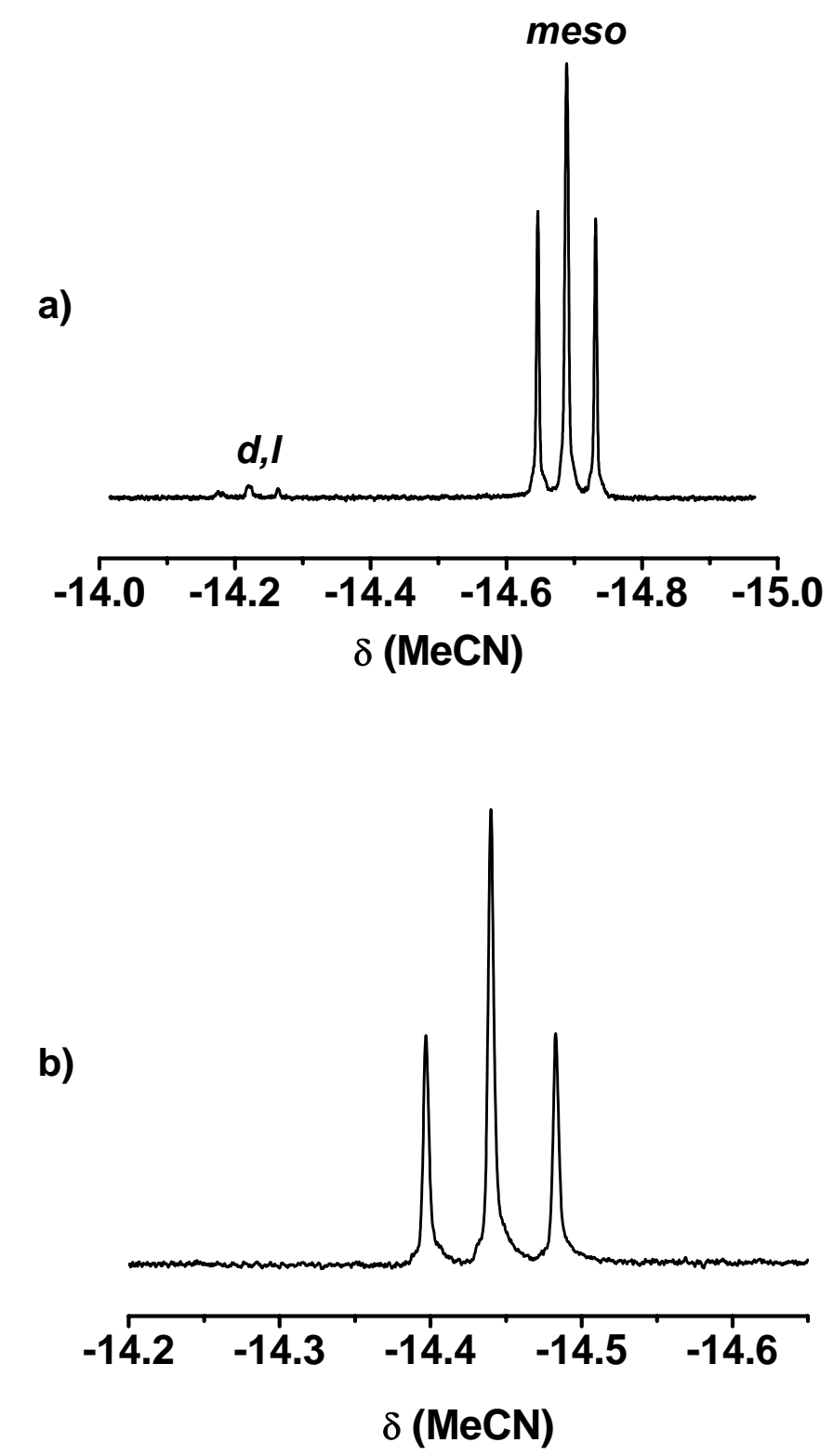

Figure S9. ${ }^{1} \mathrm{H}$ NMR $(\mathrm{MeCN})$ of the $\mu$-Hydride signal of a) $\left[\mathrm{Fe}_{2}\left[(\mathrm{SCHMe})_{2} \mathrm{NH}\right](\mu-\right.$ $\left.\mathrm{H})(\mathrm{CO})_{4}\left(\mathrm{PMe}_{3}\right)_{2}\right]^{+}$, where $\delta-14.26$ and $\delta-14.7$ are the $d, I-$ and meso-isomers respectively. The $\mathrm{J}_{\mathrm{H}-\mathrm{P}}$ is 21.3 and $21.4 \mathrm{~Hz}$ for the meso-isomer and 21.1 and $21.5 \mathrm{~Hz}$ for the $d, l$-isomer. b) $\left[\mathrm{Fe}_{2}\left[\left(\mathrm{SCH}_{2}\right)_{2} \mathrm{NH}\right](\mu-\mathrm{H})(\mathrm{CO})_{4}\left(\mathrm{PMe}_{3}\right)_{2}\right]^{+}$, where $\delta$ 14.44 and $\mathrm{J}_{\mathrm{H}-\mathrm{P}}=21.4$ and $21.5 \mathrm{~Hz}$. 


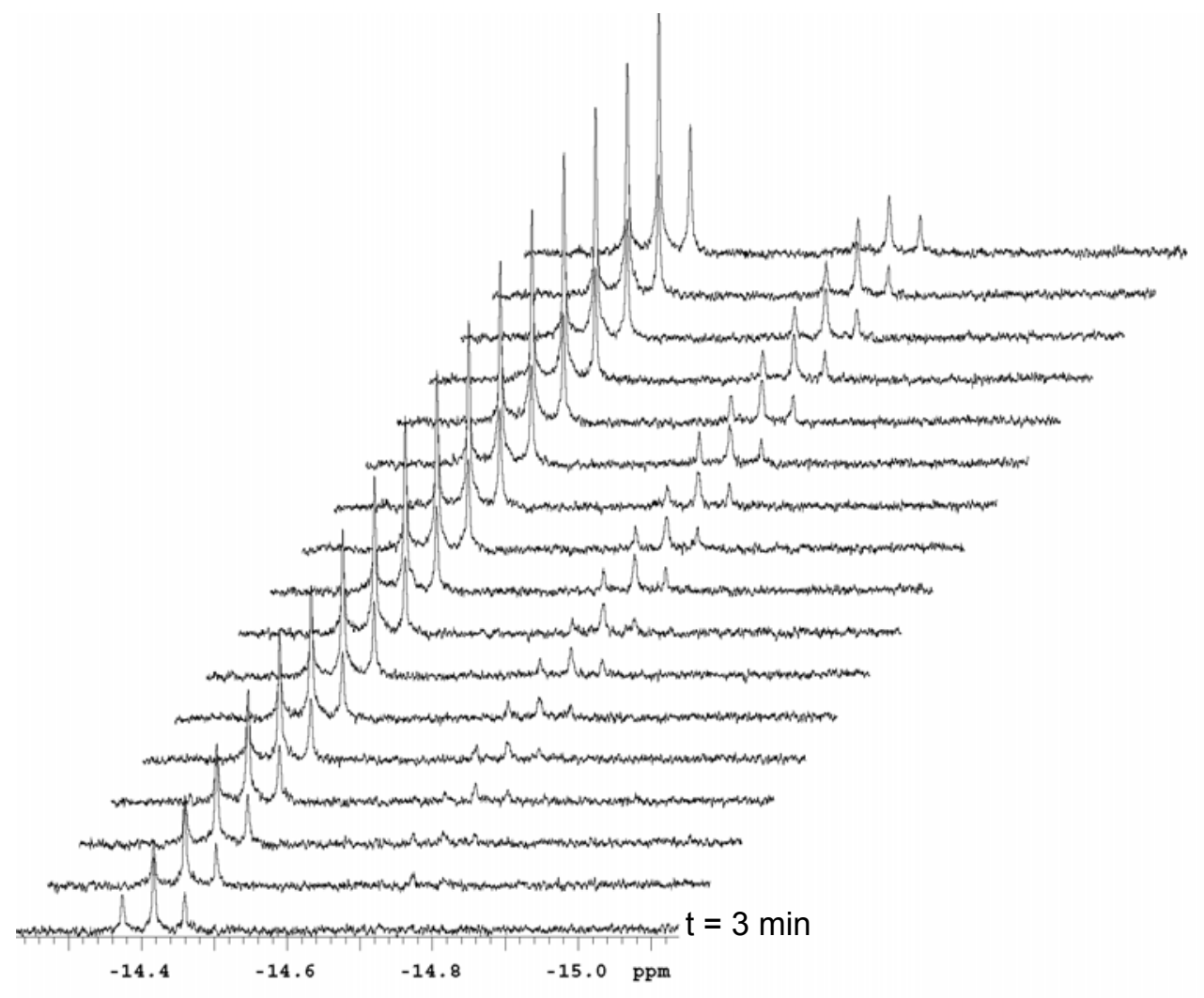

Figure S10. A stacked plot demonstrating the the tautomerization to the $\mu-\mathrm{H}$ species for $\left[\mathrm{Fe}_{2}\left[(\mathrm{SCHMe})_{2} \mathrm{NH}_{2}\right](\mathrm{CO})_{4}\left(\mathrm{PMe}_{3}\right)_{2}\right]^{+}(\delta-14.7)$ and $\left[\mathrm{Fe}_{2}\left[\left(\mathrm{SCH}_{2}\right)_{2} \mathrm{NH}_{2}\right](\mathrm{CO})_{4}\left(\mathrm{PMe}_{3}\right)_{2}\right]^{+}(\delta-14.4)$ in $\mathrm{CD}_{3} \mathrm{CN}$. The first spectrum was obtained 3 min after the sample was thawed, with each subsequent spectrum being 50 min later than the previous one. 
a)

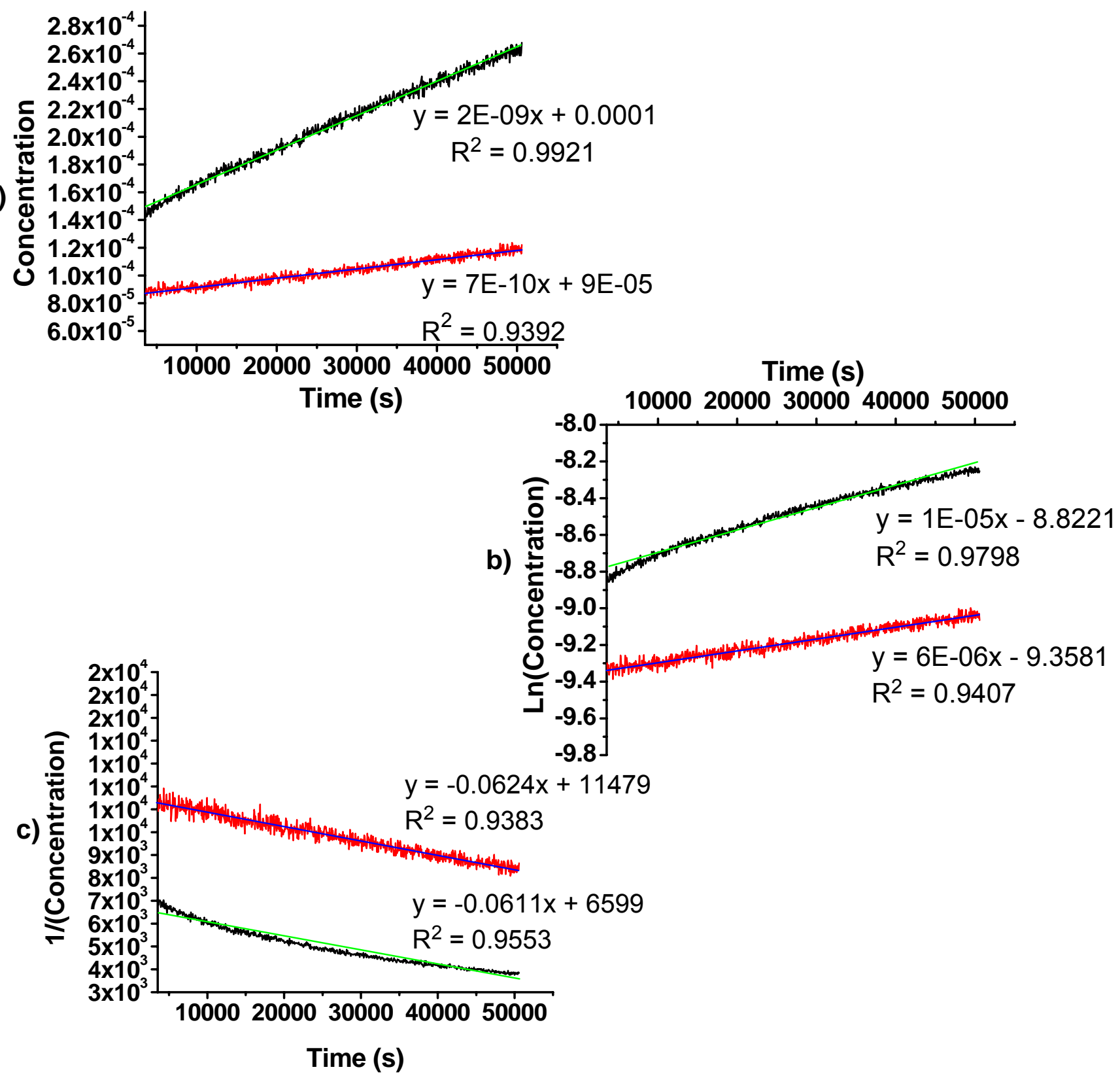

Figure S11. Rate of formation of the $\mu-\mathrm{H}$ species from in situ formed

$\left[\mathrm{Fe}_{2}\left[(\mathrm{SCHMe})_{2} \mathrm{NH}_{2}\right](\mathrm{CO})_{4}\left(\mathrm{PMe}_{3}\right)_{2}\right]^{+}$(red line) and

$\left[\mathrm{Fe}_{2}\left[\left(\mathrm{SCH}_{2}\right)_{2} \mathrm{NH}_{2}\right](\mathrm{CO})_{4}\left(\mathrm{PMe}_{3}\right)_{2}\right]^{+}$(black line) based on integrations normalized to a standard $\left(\mathrm{Ph}_{3} \mathrm{CH}\right)$ where the data has been fit to a) Zeroth, b) First and c)

Second order plots. The first hour was omitted to allow for protonation equilibration. 
$p K_{a}$ Determinations

\section{7) Experimental for Determination of $\mathrm{pK}_{\mathrm{a}}$ values}

Approximately $30-60 \mathrm{mg}$ of $\mathrm{Fe}_{2}\left[(\mathrm{SCHR})_{2} \mathrm{NR}\right](\mathrm{CO})_{4-x}\left(\mathrm{PMe}_{3}\right)_{\mathrm{x}}$, where $\mathrm{x}=$ 0,2 , was taken up into $20-30 \mathrm{~mL}$ of $\mathrm{MeCN}$ resulting in a $\mathrm{M}$ solution. A stock solution was prepared of the desired acid in MeCN. Using a solution IR cell, an IR spectrum was obtained of the compound in $\mathrm{MeCN}$ without any acid present. One equivalent of the acid in $\mathrm{MeCN}$ was transferred into the reaction vessel and allowed to stir for $1 \mathrm{~min}$ before a sample was removed for an IR spectrum. About five minutes elapsed before another equivalent of acid was added to the reaction, stirred for $1 \mathrm{~min}$ and then re-analyzed. Acid additions were repeated $\sim 4-5$ times until the protonated and unprotonated compounds overlapped too much to be differentiated reliably. All of the spectra were obtained using WINFIRST IR software and were then converted to ASCII tables using the IR program's software and imported individually into the Microcal-Origin program (Fig. S12).

Note: MeCN was used as a solvent due its large dielectric constant (37.5) to minimize ion pairing effects and the large tabulation of $\mathrm{pK}_{\mathrm{a}}$ and homoconjugation constants of many acids. ${ }^{1}$ 


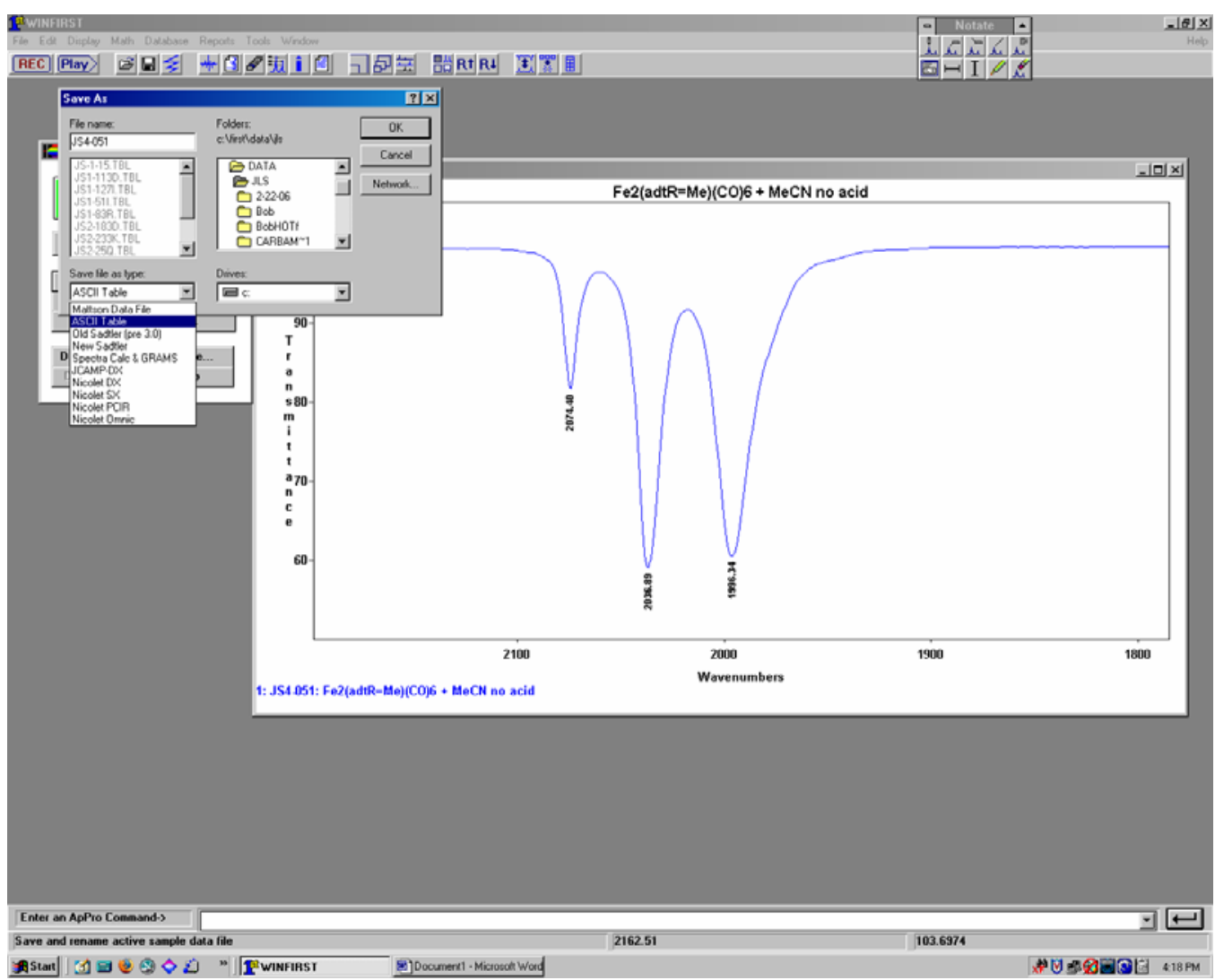

Figure S12. Picture of the conversion of raw IR data to ASCII file using WINFIRST IR software.

\section{8) Data Analysis for Determination of $\mathrm{pK}_{\mathrm{a}}$ values}

\section{A) Multi-Gaussian Fit in Origin}

Each ASCII table was imported into a new Origin worksheet and the data was then cropped to a specific wavenumber window (i.e. $1800-2150 \mathrm{~cm}^{-1}$ ) prior to graphical analysis. [It is important to note that Origin will only analyze the data if the wavenumbers are present in ascending order ( $L$ to $R$ ) (i.e. do not reverse the spectrum as would normally be done, this will lead to complications in the curve fitting subroutine).] Once the data has been plotted it can be analyzed. Under the 'Analysis' tab is the 'Fit Multiple-Peaks' option which contains the 'Gaussian' option (Fig. S13A). 

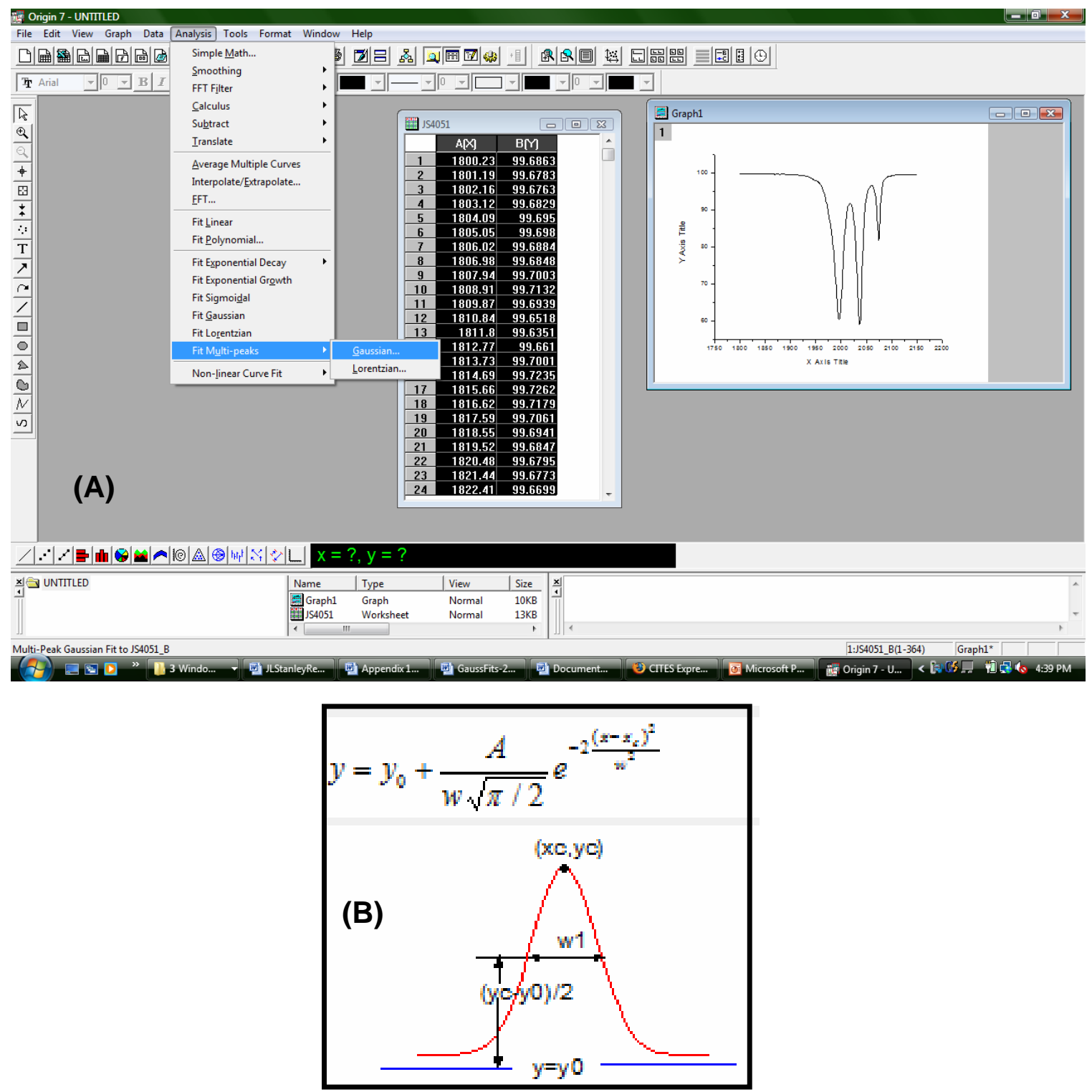

Figure S13. A) (top) Picture demonstrating location of multiple Gaussian fit option. B) (bottom) Picture showing the equation used by Origin as well as the mathematical definition of described variables. 
A dialogue box will appear requesting the number of peaks to be analyzed (Fig. S14).

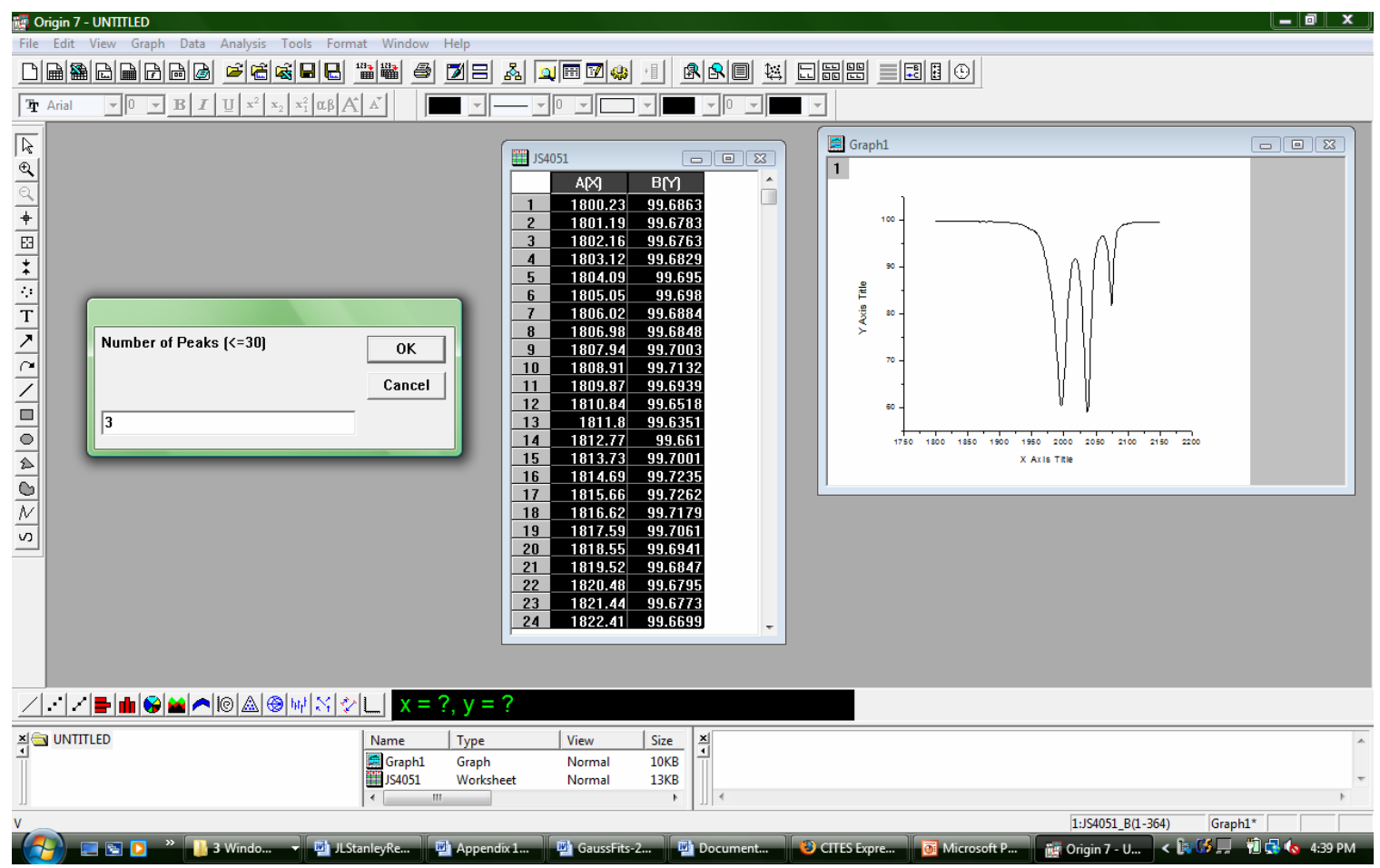

Figure S14. Picture showing dialogue box requesting the number of peaks to

be fit to the Gaussian function.

A second dialogue box will then request an initial half width estimate for the peaks. This is an arbitrary number giving the curve fitting subroutine an initial guess, where excessively large numbers tend to give unreliable results (Fig S15). 


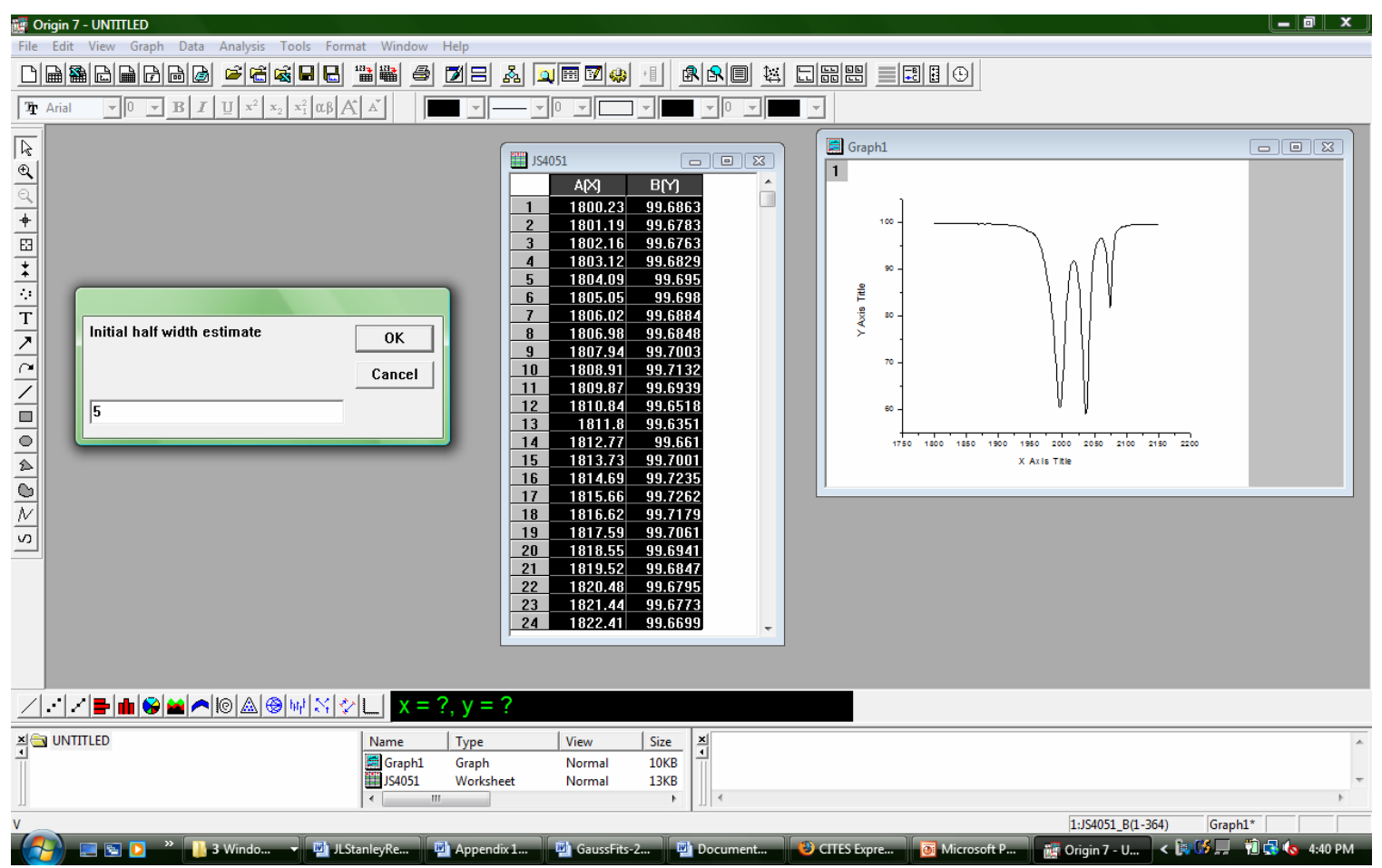

Figure S15. A picture showing a dialogue box requesting the initial guess for

the initial half width of peaks to be fitted with the Gaussian functions.

A cursor will then appear and you will be allowed to indicate the peaks to be analyzed. A double click is used to place the green dotted cursor lines indicating the maxima of peak locations (Fig. S16).

Note : Peak picking must occur from the leftmost peak to the rightmost peak. 


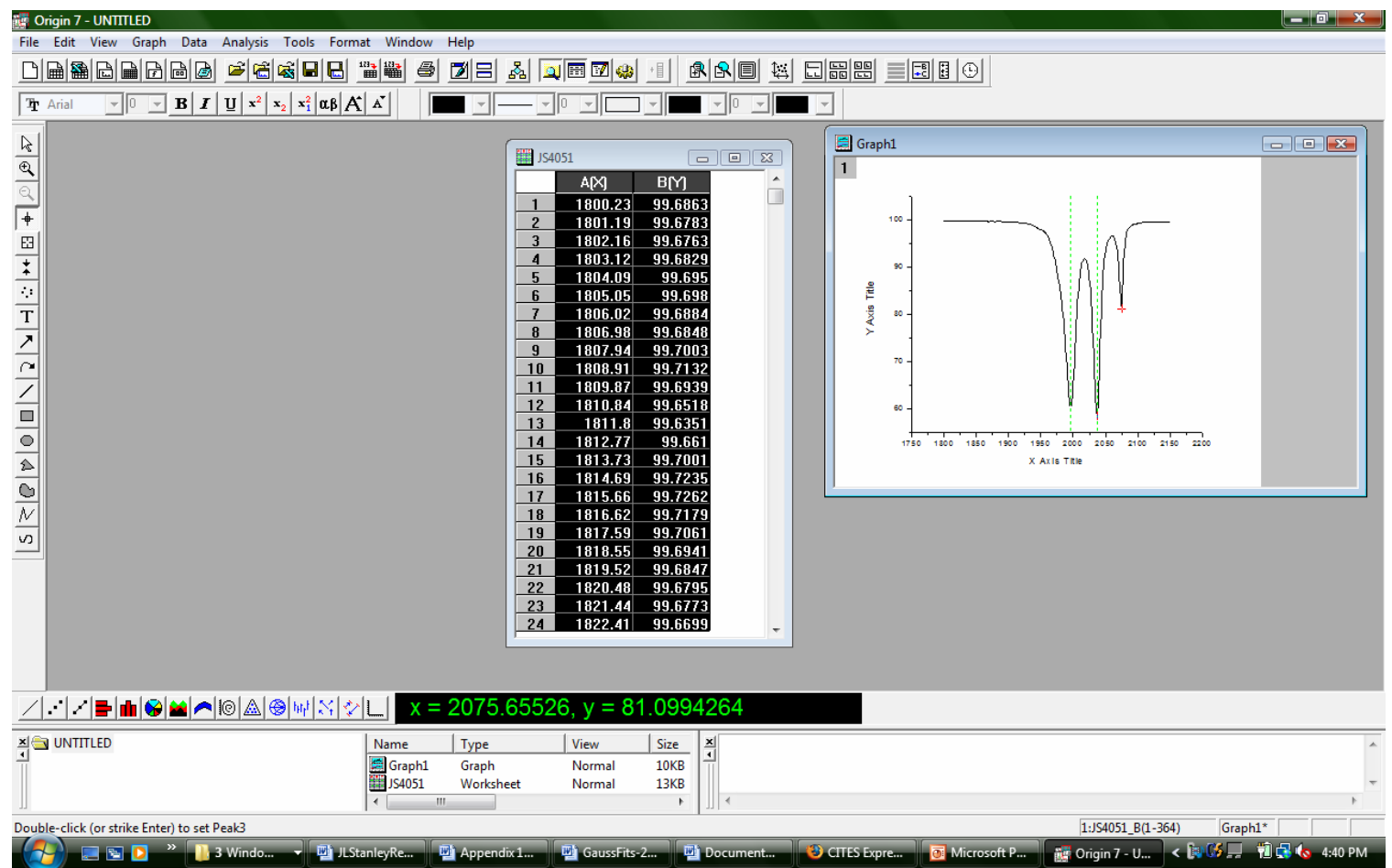

Figure S16. A picture demonstrating the selection of peaks to be fit by the

Gaussian subroutine.

A text box on top of the analyzed spectrum will appear containing the equation used to calculate the Gaussian fits. The variables in the equation are denoted with numbers that correspond to the peaks in the order in which were identified in the previous step (leftmost peak is denoted with a 1 , next peak is a 2 etc.). Also, a dialog box located at the bottom of the screen will contain the peak areas, which are identified by the wavenumber of the maxima of the peaks (Fig. S17). The green lines on the analyzed spectrum correspond to the individual Gaussian fits that Origin assigned to each peak. The red line corresponds to the overall Gaussian fit. 


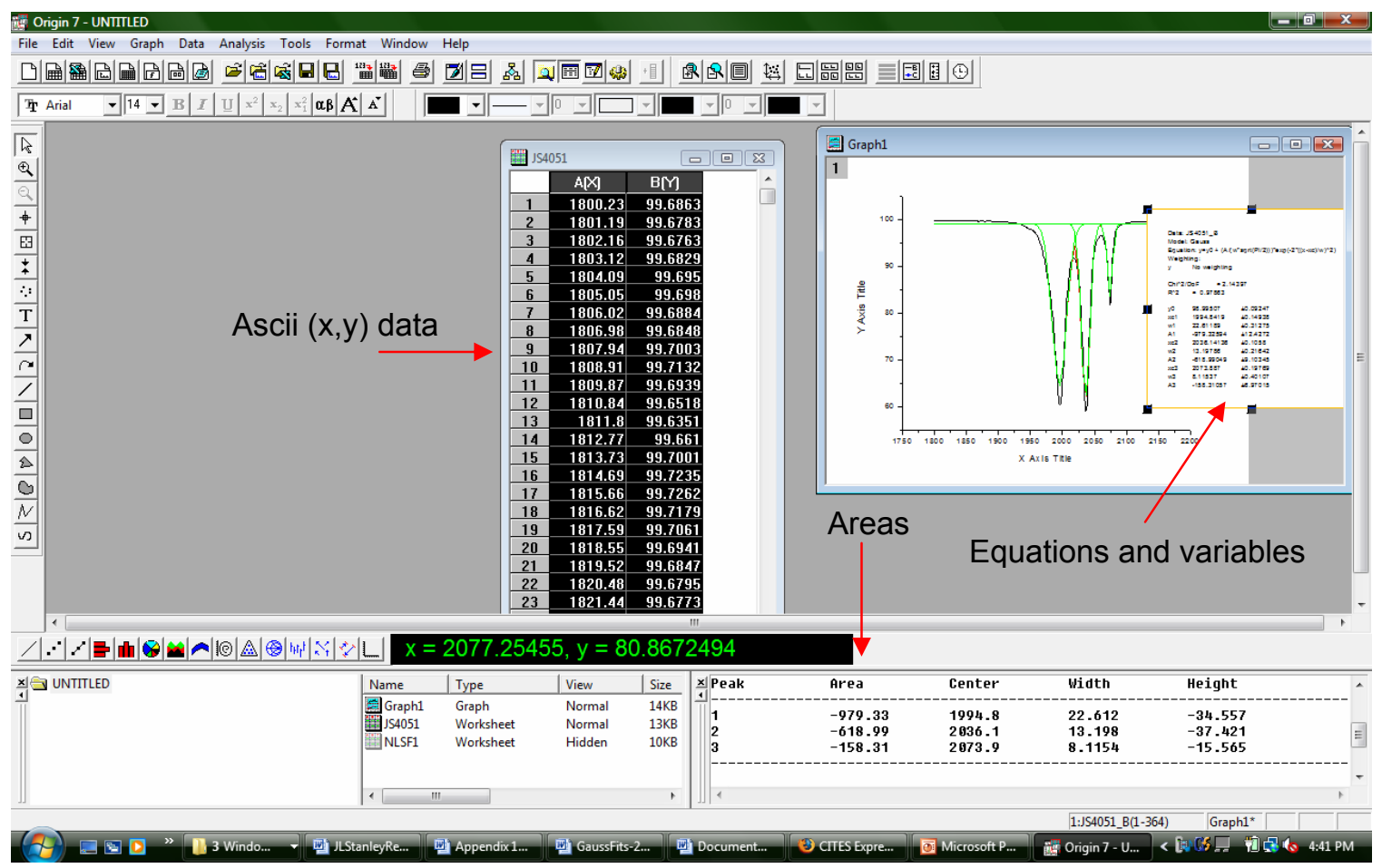

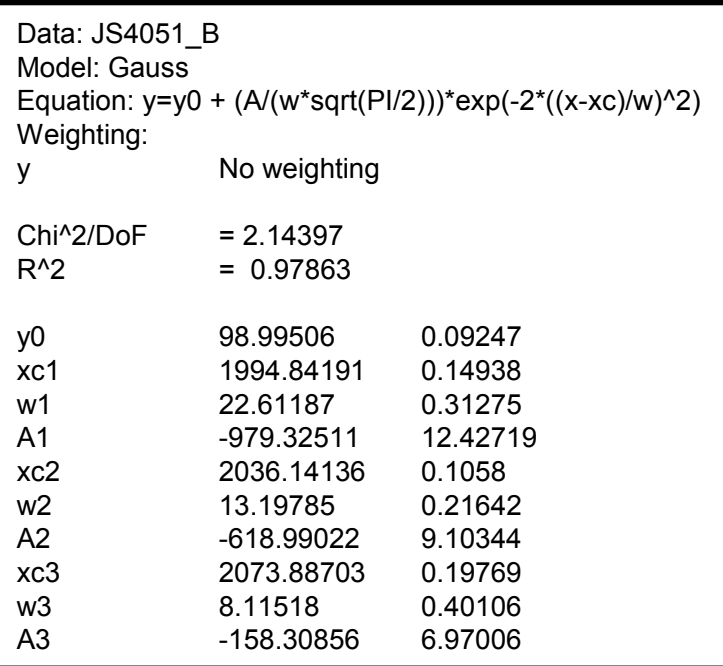

Figure S17. Picture showing overall Gaussian fit results (top) and a closer look at the table produced by the Origin Gaussian fit subroutine (bottom). 


\section{B) Data Manipulation Using Excel and Gaussian Fit Results with Origin}

In fitting the data, Origin attempts to use all of the peaks to give an overall fit to the whole spectrum which can often distort/skew the contributions of the individual peaks themselves (Fig. S17). Several pieces of the data need to be transferred into Excel to be analyzed further so that better individual fits can be obtained (Fig S18). In some cases, refits will drastically alter the value of the area under the peak that was originally assigned by Origin. The following data needs to be transferred to Excel: the ascii table values $(x, y)$, all the data inside the text box located on top of the spectrum and the area values that correspond to the peaks.

An example of the prepared Excel sheet can be found in Fig. S18 (below). Fit 1, Fit 2, etc correspond to the peaks picked with the same numbering as described previously (i.e. Fit $1=$ Peak 1 , Fit $2=$ Peak 2 , etc.). The columns ' $x c$ ' and ' $y$ ' correspond to the ascii $x$ and $y$ values (wavenumber and \% Transmittance, respectively) and will plot as the IR spectrum (the black line in Fig. S18). The 'Fit' columns I,J, and K in Fig. S18 need to contain the same equation as that provided by Origin (Cell A3 in Fig. S18) with the variables linked to the cells with the appropriate numerical labels (ex. Fit 1 has xc1, w1, A1) (columns A-C in Fig. S18). The summation (column L in Fig S18) of all the Fit values (columns $\mathrm{H}, \mathrm{I}, \mathrm{J}$, and $\mathrm{K}$ in Fig. S18) added to the y0 value (cell B10 in Fig. S18) will result in the Gaussian line calculated by Origin (the red line in Fig. S18). 


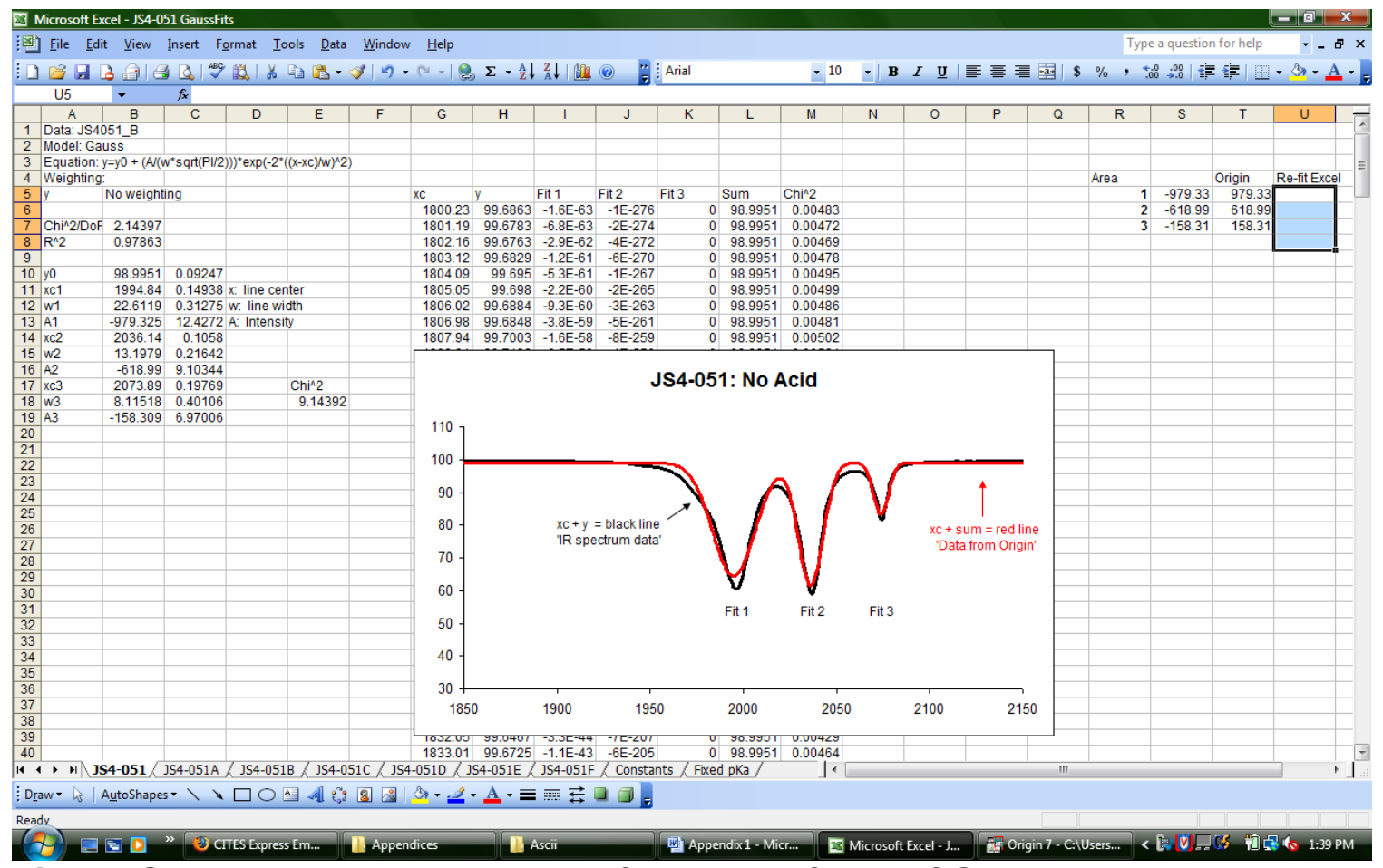

Figure S18. Picture showing set up for manual fitting of Guassian peaks using Excel.

Note: $\mathrm{Chi}^{2}$ may be calculated to determine a goodness of fit by the following equation:

$$
\frac{\left(\% T-\% T_{A}\right)^{2}}{\% T_{A}}
$$

where $\% \mathrm{~T}$ and $\% \mathrm{~T}_{\mathrm{A}}$ are the original and the adjusted $\% \mathrm{~T}$ values (columns $H$ and $L$ in Fig. S18) respectively.

C) Manual Adjustment of Gaussian Fits

The Gaussian fit calculated by Origin may be the best overall fit for the data but it is not the best fit for each individual peak! The red line can be adjusted manually in Excel to provide the best fit for each peak but this 
must be done visually. The $x \mathrm{x} \#, \mathrm{w \#}$ and $\mathrm{A \#}$ values can be changed and if the cells are correctly linked, so will the resulting sum column which will in turn change the location, shape and intensity of the red line (Fig. S19).

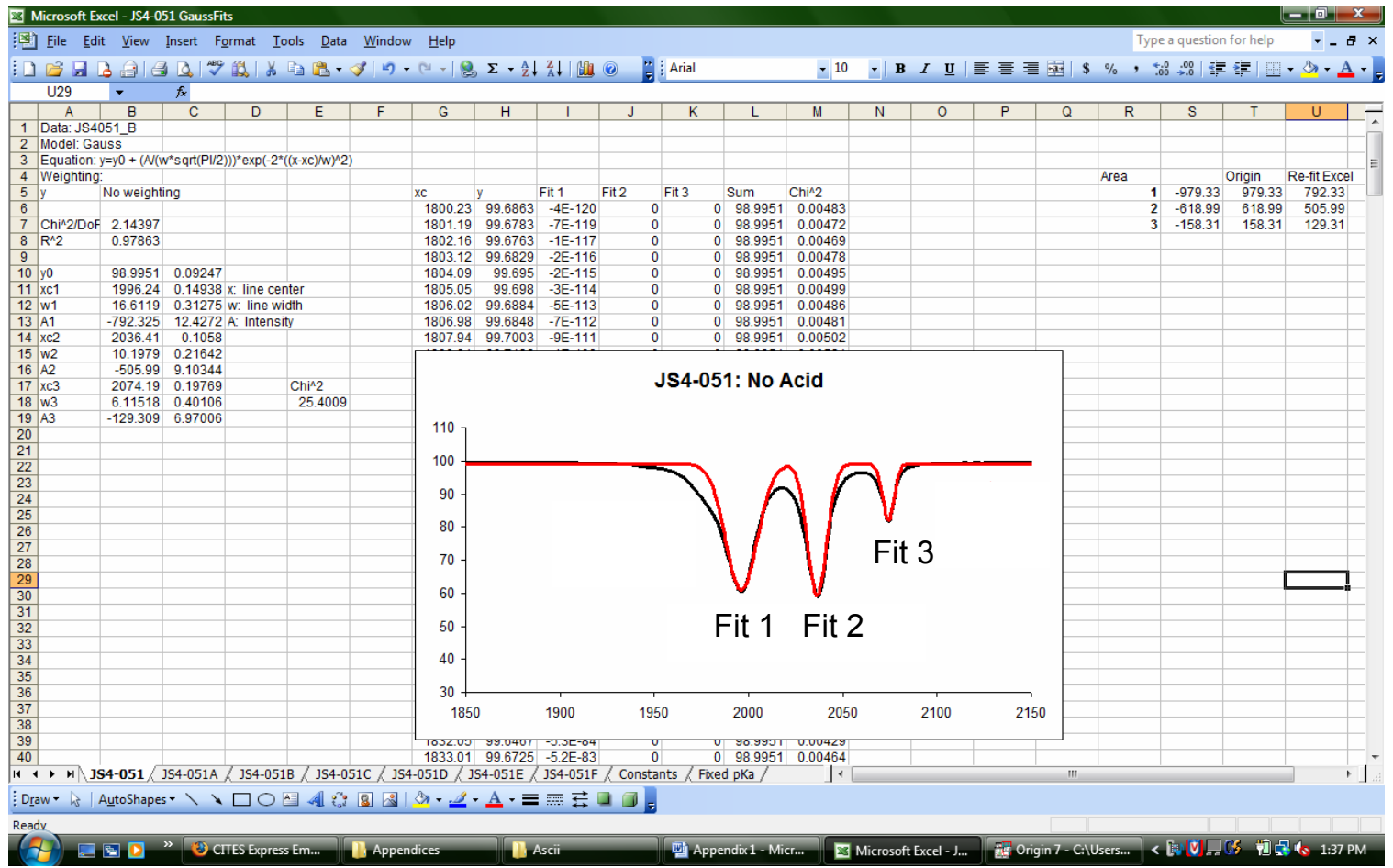

Figure S19. Picture of manual fitting of Gaussian peaks to experimental data using Excel.

\section{D) Obtaining Final Area Values Using Re-fitted Data}

The data from the visual re-fits can be copied and pasted back into the current Origin project on a new worksheet: the xc column and whichever Fit columns need to be re-analyzed. Now in Origin, the xc column can be plotted with each individual Fit column. The 'new' area under the curve can be calculated by going to the Analysis tab and choosing the Gaussian Fit option. 
Again, a dialogue box will appear on the graph chosen and the area value(s) will be located on the bottom of the screen (Fig. S20).

That new area value can be pasted into Excel and compared to the old value and used for further $\mathrm{pK}_{\mathrm{a}}$ determination.

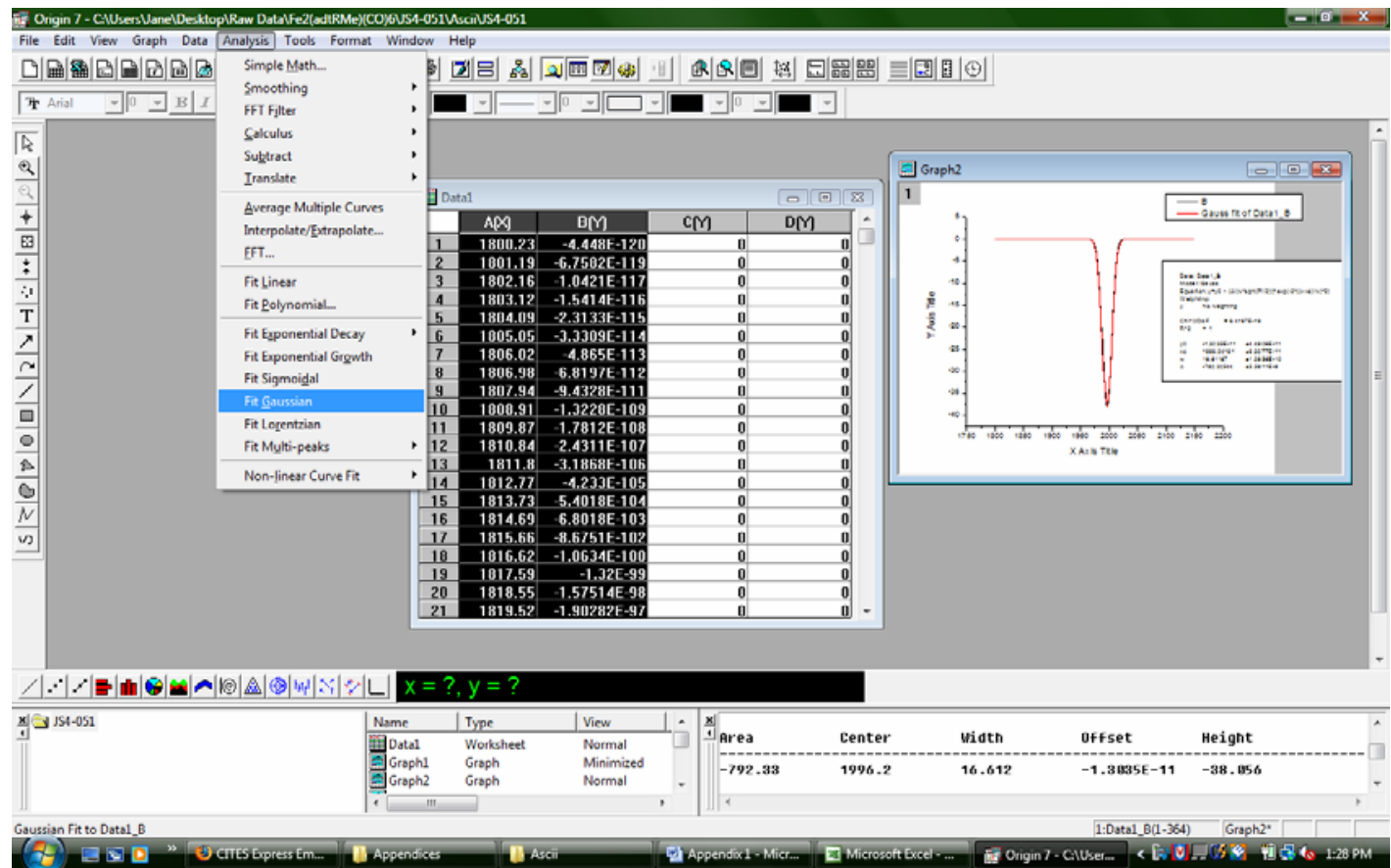

Figure S20. Picture showing the visual adjustment of a single Gaussian peak for the purpose of obtaining the area underneath the peak.

\section{9) Determination of $\mathrm{pK}_{\mathrm{a}}$ value}

Homoconjugation effects were determined through the equations shown in Scheme S1. The species present in the solution were first determined and a balanced equation was then written. Removal of the homoconjugation constants and dissociation constants of the respective acid were removed from the overall equation using equilibrium calculations as seen in Scheme S1. The left over species were found represent $1 / \mathrm{K}_{\mathrm{a}}{ }^{2}$ for the protonation of $\mathrm{Fe}_{2}\left[(\mathrm{SCHR})_{2} \mathrm{NR}\right](\mathrm{CO})_{4-}$ ${ }_{x}\left(\mathrm{PMe}_{3}\right)_{x}$, where $\mathrm{x}=0,2$ and $\mathrm{R}=\mathrm{Me}, \mathrm{H}$. The $\mathrm{K}_{\mathrm{a}}$ expression can then be written 
in known quantities using the known equilibrium constants shown in Scheme S1. To determine the value of $\mathrm{K}_{\text {eq }}$ the expression must be written in terms of quantities that can be measured; determination of the quantities involved in the calculation of $\mathrm{K}_{\mathrm{eq}}$ are shown in Figure S21.

Scheme S1. Equilibrium calculations used to determine $\mathrm{pK}_{\mathrm{a}}$ values for protonation of $\mathrm{Fe}_{2}\left[(\mathrm{SCHR})_{2} \mathrm{NR}\right](\mathrm{CO})_{4-x}\left(\mathrm{PMe}_{3}\right)_{x}$ complexes, where $\mathrm{x}=0,2$ and $\mathrm{R}$ $=\mathrm{Me}, \mathrm{H}$.

Overall Reaction: $\mathrm{ML}_{n}+\mathrm{HA} \rightleftharpoons \mathrm{AHA}^{-}+\mathrm{A}^{-}+\mathrm{ML}_{n} \mathrm{H}^{+}$

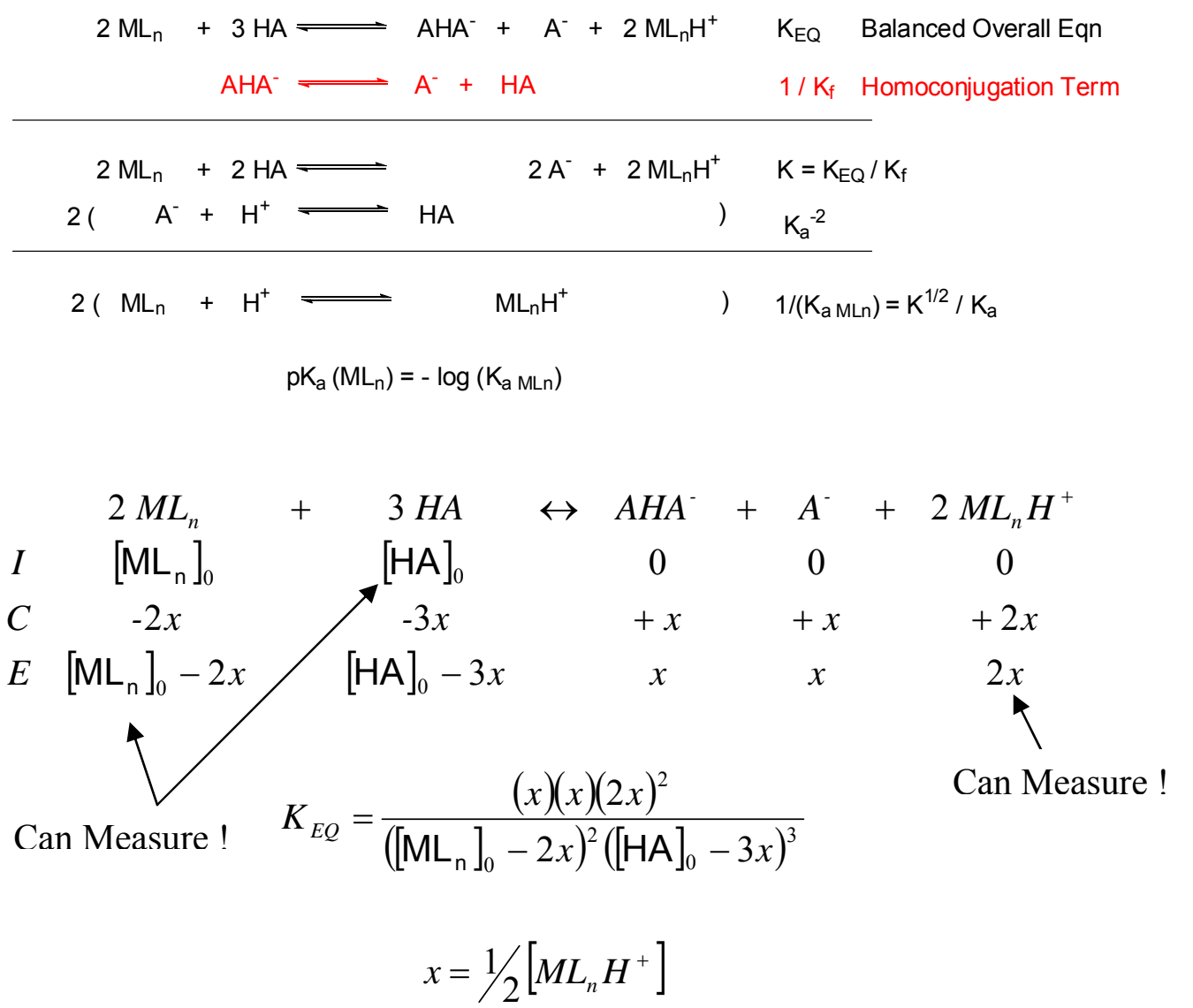

Figure S21. Equilibrium expression showing the determination of $\mathrm{K}_{\mathrm{eq}}$ from known measurable quantities. 
The following assumptions were taken into consideration when determining $\mathrm{K}_{\text {eq }}$ values:

1) All $H^{+}$formed protonates $M L_{n}$ to $M L_{n} H^{+}$(no solvated $H^{+}$)

2) $\mathrm{AHA}^{-}$is the only homoconjugation species formed

3) No decomposition occurs during protonation

4) $K_{a}$ and $K_{f}$ have known values

\section{0) Gaussian Fits From Origin (before Excel re-fit) for $\mathrm{Fe}_{2}\left[(\mathrm{SCHMe})_{2} \mathrm{NH}\right](\mathrm{CO})_{6}$.}

No Acid

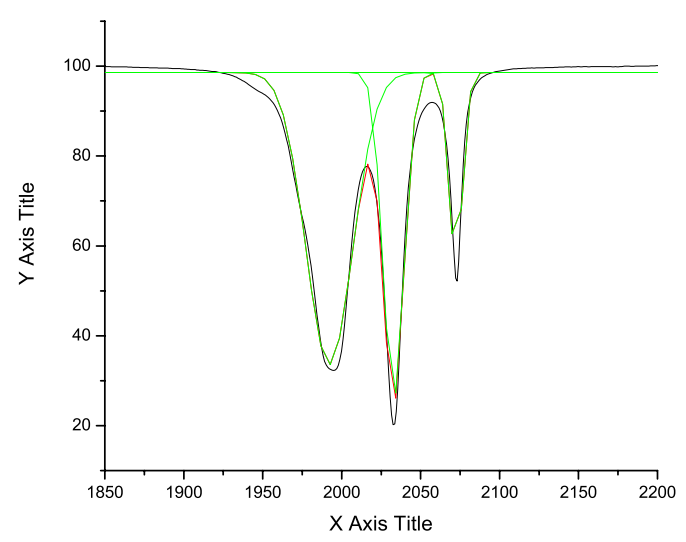

2 equiv. HOTs

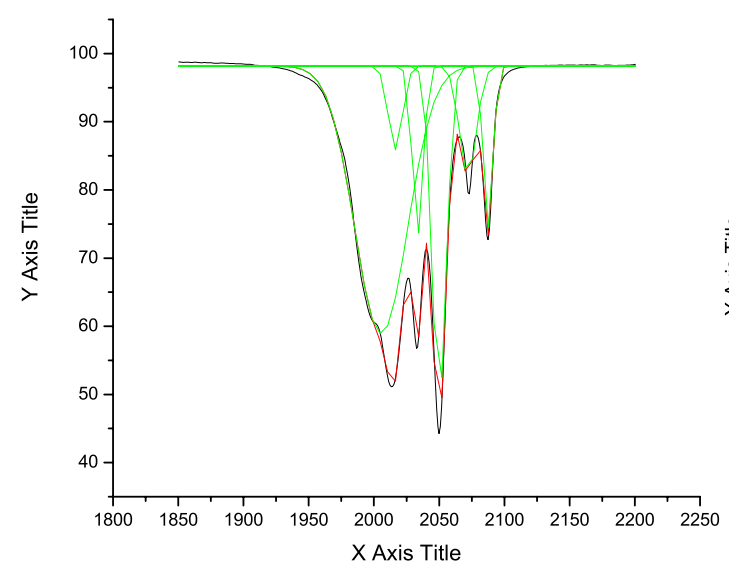

1 equiv. HOTs

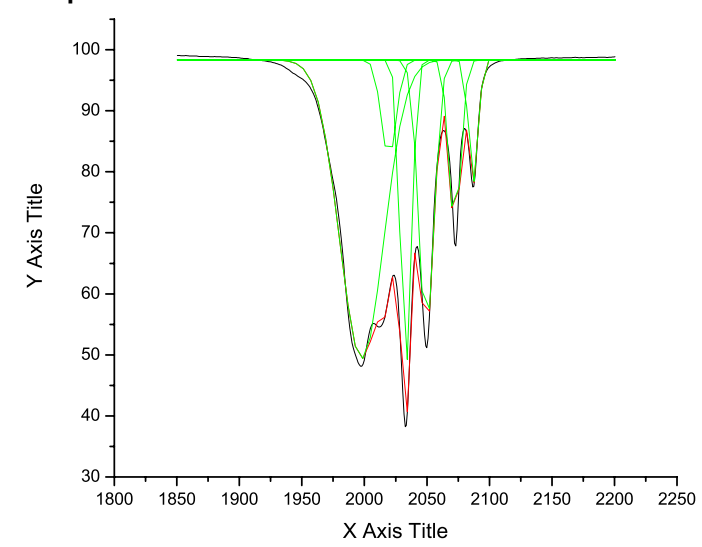

3 equiv. HOTs

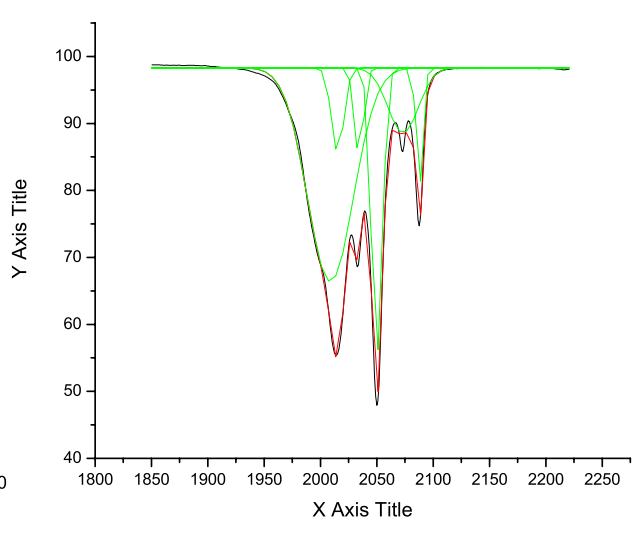


4 equiv. HOTs

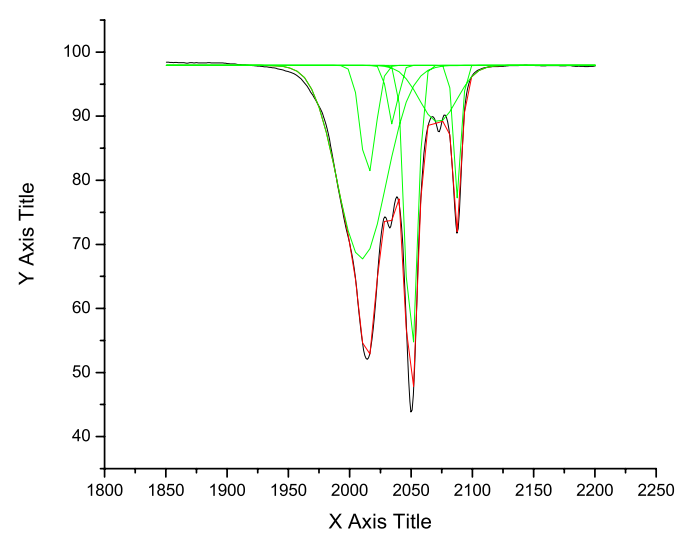

5 equiv. HOTs

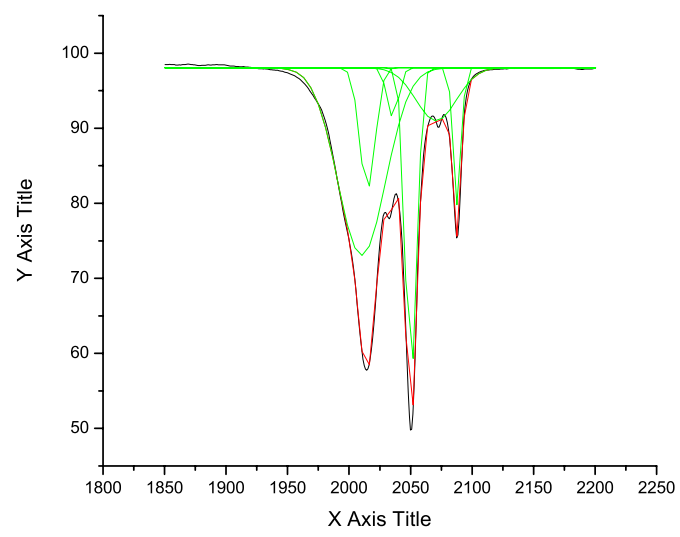

11) Gaussian Visual Re-Fits From Excel for $\mathrm{Fe}_{2}\left[(\mathrm{SCHMe})_{2} \mathrm{NH}\right](\mathrm{CO})_{6}$.

No Acid

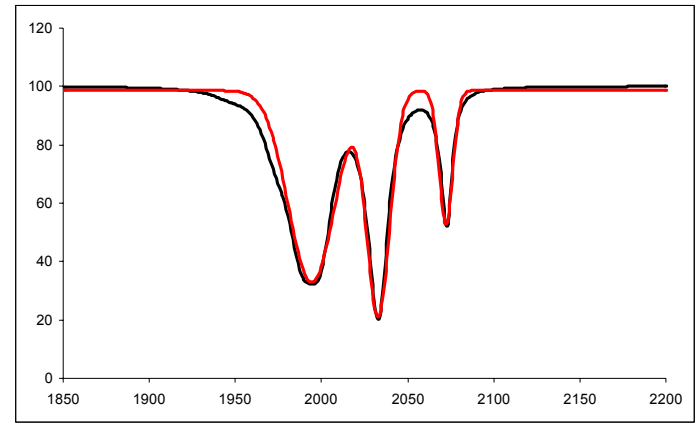

2 equiv. HOTs

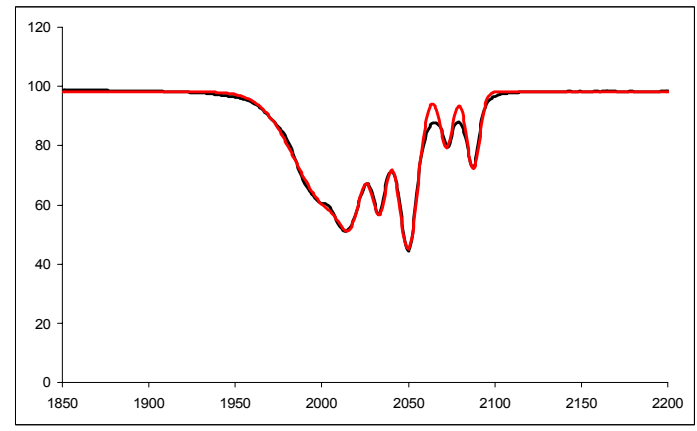

1 equiv. HOTs

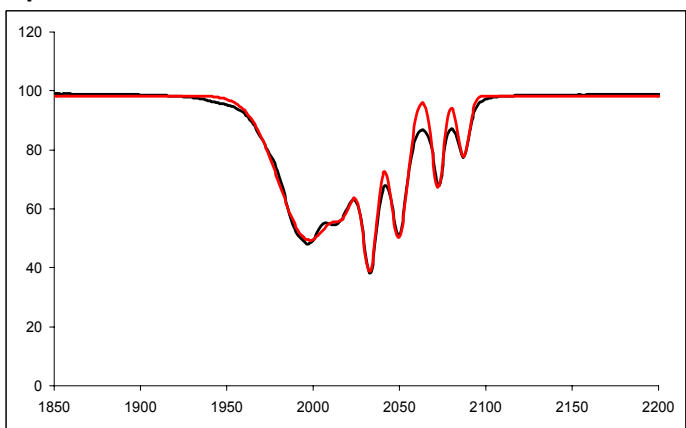

3 equiv. HOTs

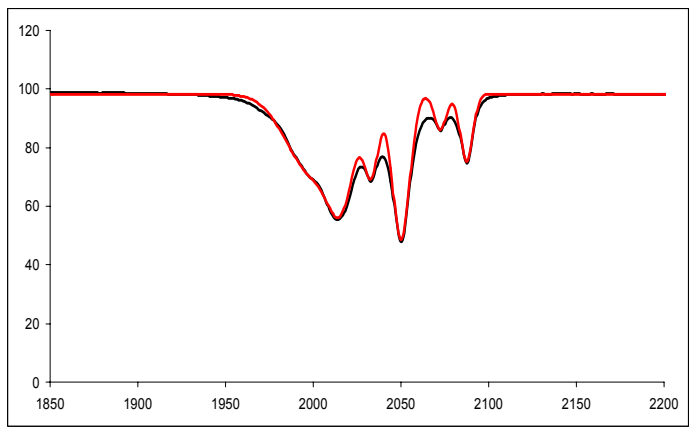


4 equiv. HOTs

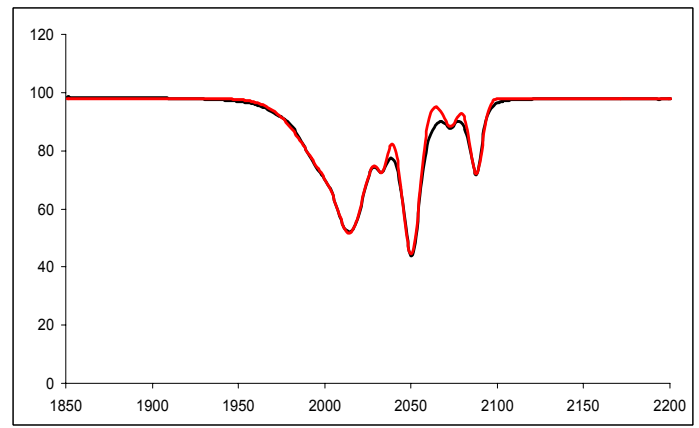

5 equiv. HOTs

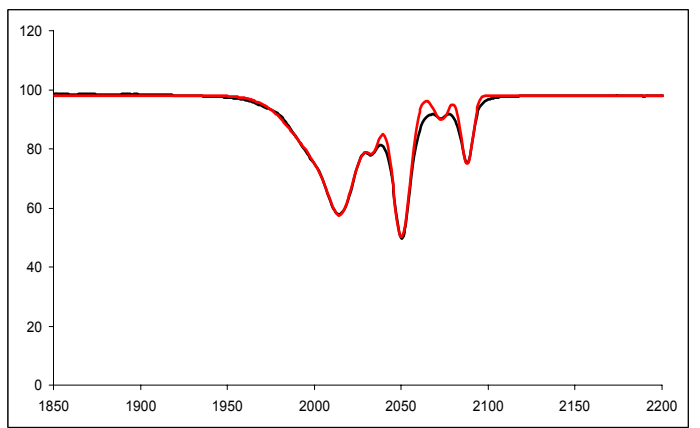

\section{DFT Results}

\section{2) DFT relative energies for $\mathrm{CH}_{2}(\mathrm{CHMe})_{2} \mathrm{~S}_{2} \mathrm{NH}$ isomers}

Scheme S2. DFT relative energies for $\mathrm{CH}_{2}(\mathrm{CHMe})_{2} \mathrm{~S}_{2} \mathrm{NH}$ isomers

$G$
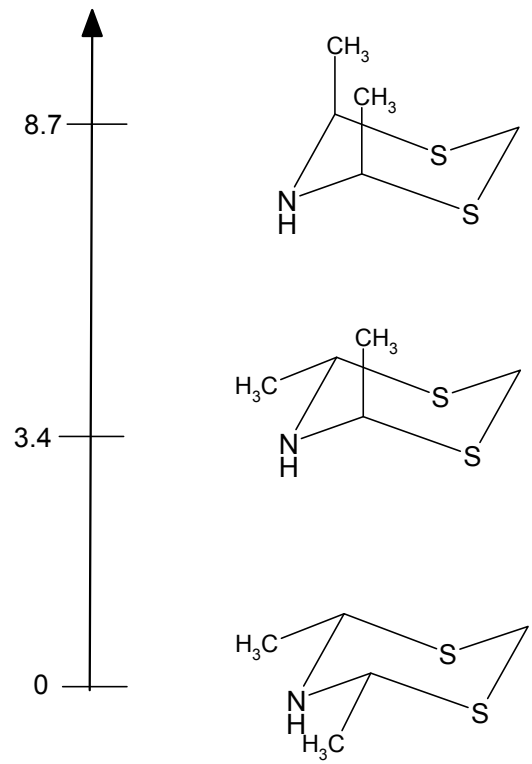
13) $\quad v \mathrm{CO}\left(\mathrm{cm}^{-1}\right)$ computed for $\mathrm{Fe}_{2}\left[(\mathrm{SCHMe})_{2} \mathrm{NH}\right](\mathrm{CO})_{6}$ and $\left[\mathrm{Fe}_{2}\left[(\mathrm{SCHMe})_{2} \mathrm{NH}_{2}\right](\mathrm{CO})_{6}\right]^{+}$

Table S2. Relevant DFT vibrational frequencies $\left(\mathrm{cm}^{-1}\right)$ computed for $\mathrm{Fe}_{2}\left[(\mathrm{SCHMe})_{2} \mathrm{NH}\right](\mathrm{CO})_{6}$ and $\left[\mathrm{Fe}_{2}\left[(\mathrm{SCHMe})_{2} \mathrm{NH}_{2}\right](\mathrm{CO})_{6}\right]^{+}$. Vibrational frequencies ascribed to stretching of distal or proximal $\mathrm{CO}$ ligands are labeled $p$ and $d$, respectively.

\begin{tabular}{c|c|c}
$\mathrm{Fe}_{2}\left[(\mathrm{SCHMe})_{2} \mathrm{NH}\right](\mathrm{CO})_{6}$ & {$\left[\mathrm{Fe}_{2}\left[(\mathrm{SCHMe})_{2} \mathrm{NH}_{2}\right](\mathrm{CO})_{6}\right]^{+}$} & $\Delta v$ \\
\hline $1969_{d}$ & $1994_{d}$ & 25 \\
$1980_{p, d}$ & $2016_{p}$ & 36 \\
$1985_{p, d}$ & $2028_{p, d}$ & 43 \\
$2002_{p, d}$ & $2042_{p, d}$ & 40 \\
$2025_{p, d}$ & $2060_{p, d}$ & 35 \\
$2061_{p, d}$ & $2093_{p, d}$ & 32 \\
\hline
\end{tabular}


14) Minimized Structures for $\mathrm{Fe}_{2}\left[(\mathrm{SCHMe})_{2} \mathrm{NH}\right](\mathrm{CO})_{6}$

\section{$\mathbf{A x} / \mathbf{E q}$}

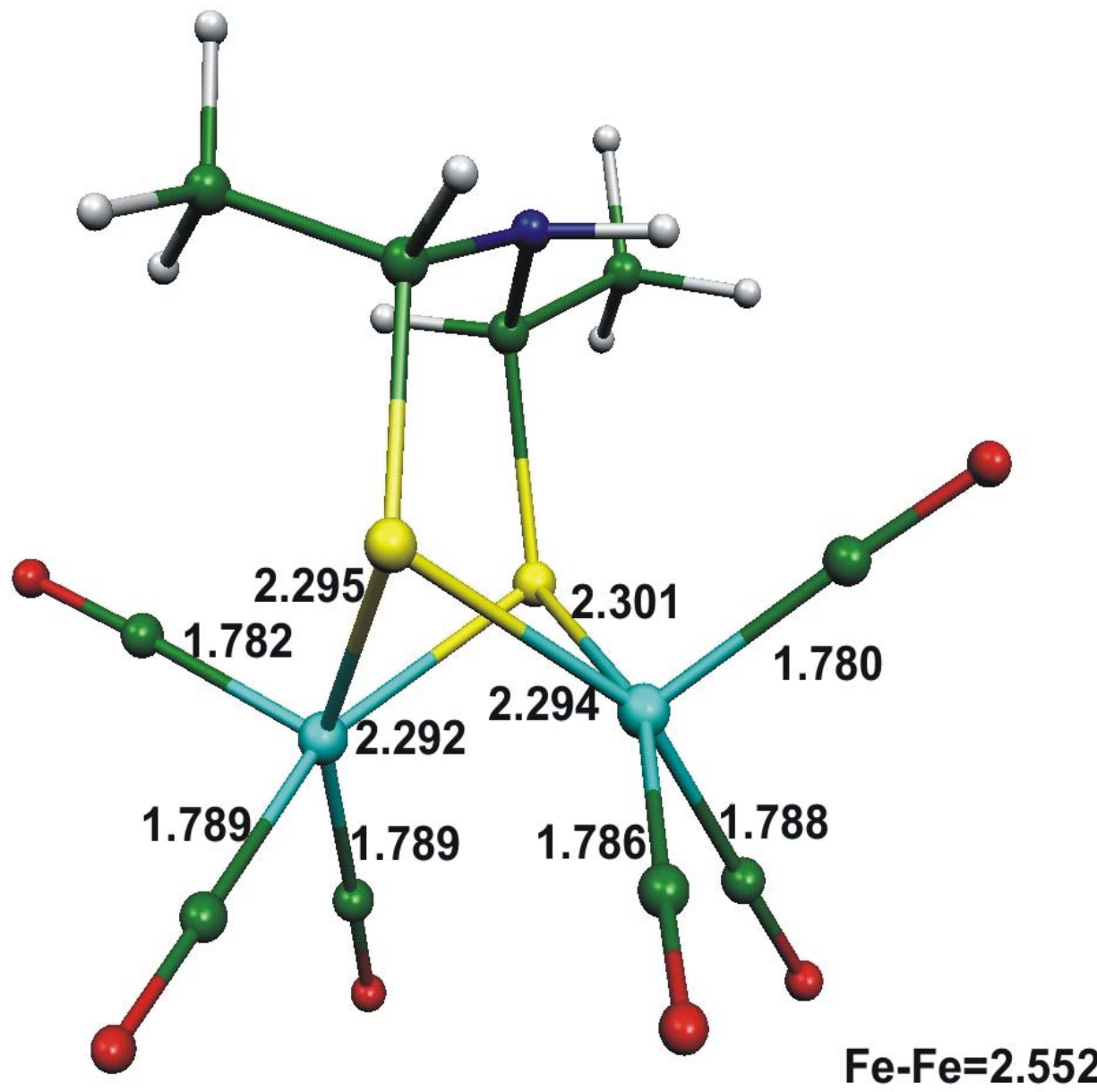




\section{$\mathbf{E q} / \mathbf{E q}$}

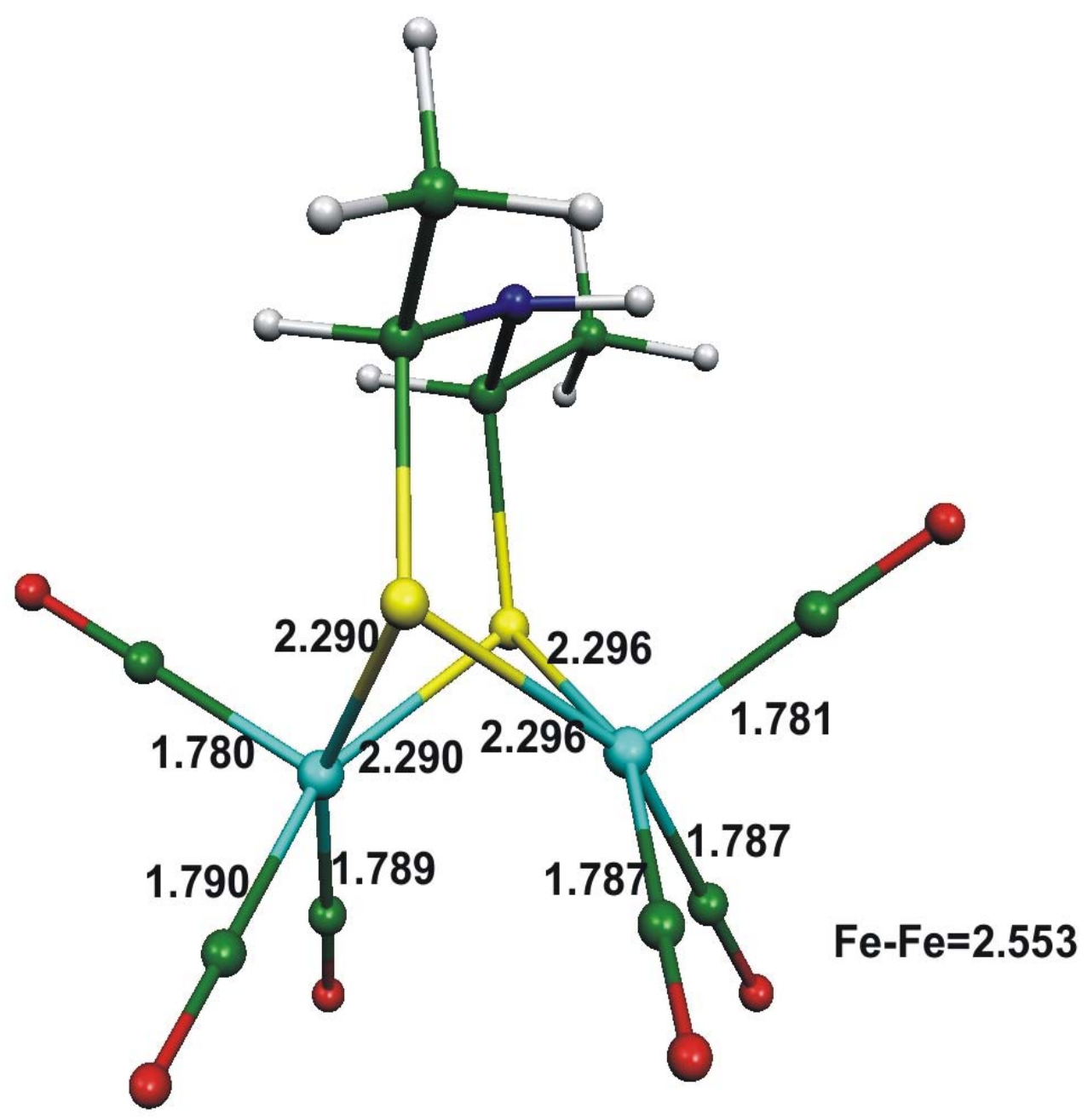

Table S3. Relative Stability Data for $243 \mathrm{~K}$ and $298 \mathrm{~K}$ as determined by DFT with B-P86 functional and high-level basis set (TZVP) to treat the electronic structure of the analyzed molecules.

\begin{tabular}{c|c|c} 
species & $\Delta \boldsymbol{G}_{243 K}$ & $\boldsymbol{\Delta G}_{298 K}$ \\
\hline Diequatorial-AxialEquatorial & 2.4 & 2.5 \\
Diequatorial-Diaxial & 6.5 & 6.6 \\
\hline
\end{tabular}

$\mathrm{Eq} / \mathrm{Eq}$ to $\mathrm{Eq} / \mathrm{Ax} \mathrm{k}_{\mathrm{eq}}=6.9 \times 10^{-3}$ at $243 \mathrm{~K}$. 


\section{5) Reference}

(1) Izutsu, K. Acid-Base Dissociation Constants in Dipolar Aprotic Solvents, 1990. 